\title{
\#USES
}

Groundwater Resources Program

Digital Surfaces and Thicknesses of Selected Hydrogeologic Units of the Floridan Aquifer System in Florida and Parts of Georgia, Alabama, and South Carolina

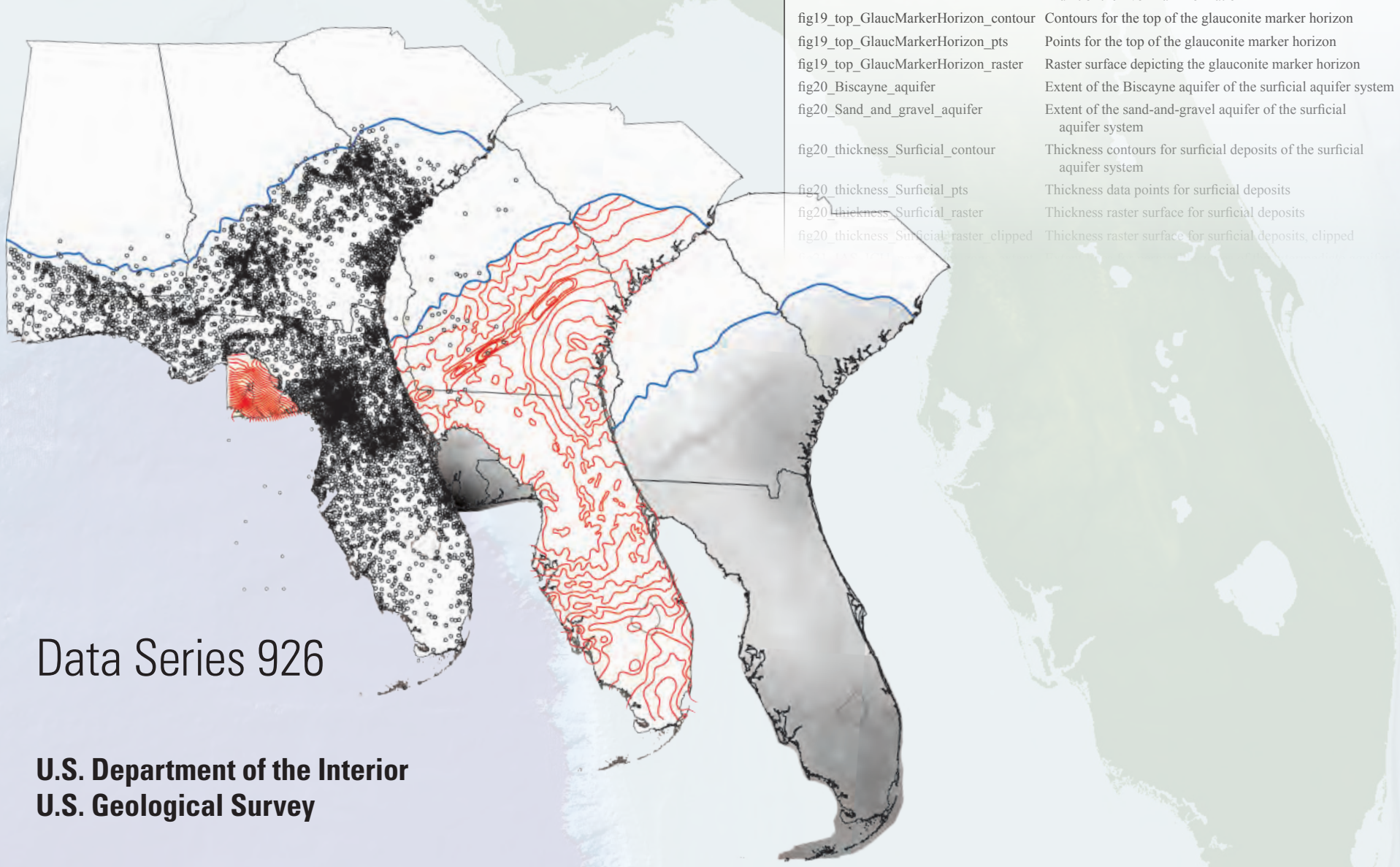





\section{Digital Surfaces and Thicknesses of Selected Hydrogeologic Units of the Floridan Aquifer System in Florida and Parts of Georgia, Alabama, and South Carolina}

By Lester J. Williams and Joann F. Dixon

Groundwater Resources Program

Data Series 926 


\title{
U.S. Department of the Interior SALLY JEWELL, Secretary
}

\section{U.S. Geological Survey Suzette M. Kimball, Acting Director}

\author{
U.S. Geological Survey, Reston, Virginia: 2015
}

For more information on the USGS - the Federal source for science about the Earth, its natural and living resources, natural hazards, and the environment-visit http://www.usgs.gov or call 1-888-ASK-USGS.

For an overview of USGS information products, including maps, imagery, and publications, visit http://www.usgs.gov/pubprod/.

Any use of trade, firm, or product names is for descriptive purposes only and does not imply endorsement by the U.S. Government.

Although this information product, for the most part, is in the public domain, it also may contain copyrighted materials as noted in the text. Permission to reproduce copyrighted items must be secured from the copyright owner.

Suggested citation:

Williams, L.J., and Dixon, J.F., 2015, Digital surfaces and thicknesses of selected hydrogeologic units of the Floridan aquifer system in Florida and parts of Georgia, Alabama, and South Carolina: U.S. Geological Survey Data Series 926, 24 p., http://dx.doi.org/10.3133/ds926.

ISSN 2327-638X (online) 


\section{Contents}

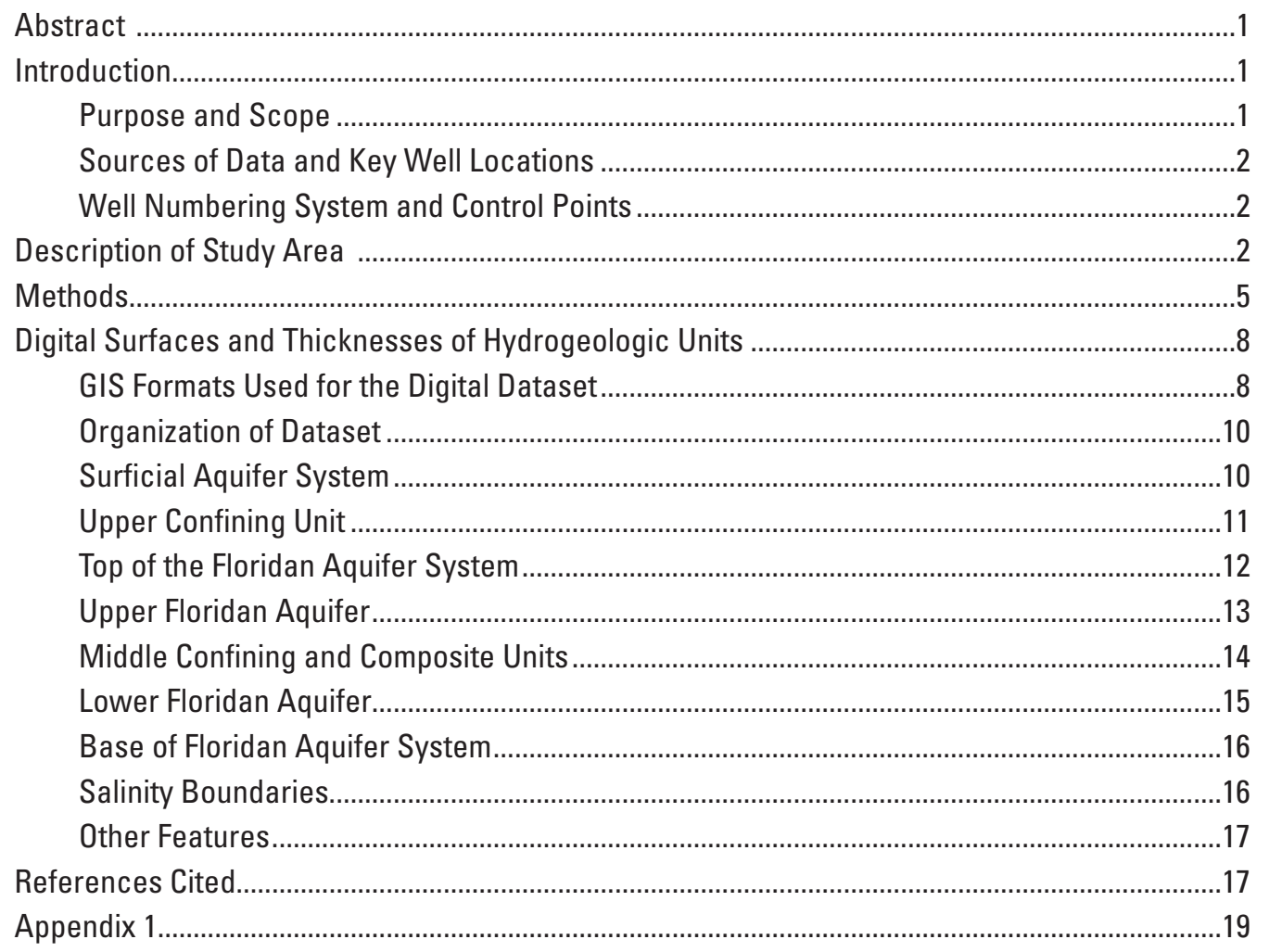




\section{Figures}

1. Study area location map showing extent of the Floridan and Southeastern Coastal Plain aquifer systems and location of key wells.

2. Generalized correlation chart showing stratigraphic units and hydrogeologic units of the Floridan and Southeastern Coastal Plain aquifer systems...

3. Graphs showing histograms of residuals between actual hydrogeologic unit altitudes determined on well logs and altitudes of the interpolated hydrogeologic surface.

4. Schematic cross section showing regional and subregional aquifers, composite units, and confining units of the Floridan aquifer system.

\section{Tables}

1. Summary statistics showing difference between actual and interpolated altitudes and thickness of hydrogeologic units and surfaces

2. Thickness rasters and other related features for the surficial aquifer system and upper confining unit.

3. Structural and thickness rasters for the Upper Floridan aquifer

4. Structural and thickness rasters for the middle confining and composite units of the Floridan aquifer system

5. Structural and thickness rasters for the Lower Floridan aquifer

6. Structural and thickness rasters and features depicting salinity boundaries in the Floridan aquifer system

1-1. Content provided in the Floridan framework geodatabase 


\section{Conversion Factors}

\begin{tabular}{lcl}
\hline \multicolumn{1}{c}{ Multiply } & By & \multicolumn{1}{c}{ To obtain } \\
\hline & Length & \\
\hline foot $(\mathrm{ft})$ & 0.3048 & meter $(\mathrm{m})$ \\
\hline & Area & \\
\hline square mile $\left(\mathrm{mi}^{2}\right)$ & 259.0 & hectare $(\mathrm{ha})$ \\
square mile $\left(\mathrm{mi}^{2}\right)$ & 2.590 & square kilometer $\left(\mathrm{km}^{2}\right)$ \\
\hline & Flow rate & \\
\hline foot per day $(\mathrm{ft} / \mathrm{d})$ & 0.3048 & meter per day $(\mathrm{m} / \mathrm{d})$ \\
\hline
\end{tabular}

\section{Supplemental Information}

Concentrations of chemical constituents in water are given in milligrams per liter (mg/L).

\section{Datums}

Vertical coordinate information is referenced to the National Geodetic Vertical Datum of 1929 (NGVD 29).

Horizontal coordinate information is referenced to North American Datum of 1983 (NAD 83).

Altitude, as used in this report, refers to distance above the vertical datum.

\section{Abbreviations}

$\begin{array}{ll}\text { APPZ } & \text { Avon Park permeable zone } \\ \text { ASCII } & \text { American Standard Code for Information Interchange } \\ \text { BZ } & \text { Boulder Zone } \\ \text { DEM } & \text { digital elevation model } \\ \text { FPZ } & \text { Fernandina permeable zone } \\ \text { GIS } & \text { geographic information system } \\ \text { GWRP } & \text { Groundwater Resource Program } \\ \text { LAPPZ } & \text { lower Avon Park permeable zone } \\ \text { LISAPCU } & \text { Lisbon-Avon Park composite unit } \\ \text { MCU } & \text { middle confining unit (Miller's MCUI through MCUVIII) } \\ \text { OCAPLPZ } & \text { Ocala-Avon Park low permeability zone } \\ \text { OLDSPZ } & \text { Oldsmar permeable zone } \\ \text { TDS } & \text { total dissolved solids } \\ \text { UCU } & \text { upper confining unit } \\ \text { UPZ } & \text { uppermost permeable zone } \\ \text { USGS } & \text { U.S. Geological Survey } \\ \text { UWI } & \text { unique well identifier }\end{array}$




\section{Acknowledgments}

The data used to develop the revised hydrogeologic framework were compiled by many different organizations and individuals. We acknowledge the contribution of Florida's five water management districts (Northwest Florida Water Management District, St. Johns River Water Management District, South Florida Water Management District, Southwest Florida Water Management District, Suwannee River Water Management District), Florida Geological Survey, Georgia Environmental Protection Division, Geological Survey of Alabama, and the South Carolina Department of Natural Resources who provided much of the data used to develop the revised hydrogeologic framework. On several occasions, Emily Richardson with the South Florida Water Management District helped locate key wells and data contained in South Florida Water Management District's DBHYDRO database. Jerry Mallams of the Southwest Florida Water Management District provided a large amount of digital well data and numerous reports concerning the hydrogeology of west-central and southwest Florida areas. Jeffery B. Davis of the St. Johns River Water Management District was particularly helpful in compiling and making available a large part geophysical log database and the hydrogeologic picks that were compiled over many years at St. Johns River Water Management District.

Jason Bellino of the U.S. Geological Survey (USGS) Tampa office assisted in scanning well logs and compiling information about the tops and bottoms of hydrogeologic units from previous regional USGS studies. We are especially grateful to Rick Spechler of the USGS Orlando office who helped locate numerous geophysical logs in the files of the USGS Orlando and Tampa offices. Ron Reese of the USGS Ft. Lauderdale office also helped locate key wells and data contained in South Florida Water Management District's DBHYDRO database. Brian Clark, Jonathan Musser, and Andrew O'Reilly, USGS, provided thorough peer reviews of the report and digital datasets. Finally, Eve Kuniansky, USGS, made significant revisions to the manuscript incorporating final comments and the editorial review of Michael Deacon. Caryl Wipperfurth, USGS, is also appreciated for illustration work and report layout. 


\title{
Digital Surfaces and Thicknesses of Selected Hydrogeologic Units of the Floridan Aquifer System in Florida and Parts of Georgia, Alabama, and South Carolina
}

\author{
By Lester J. Williams and Joann F. Dixon
}

\section{Abstract}

Digital surfaces and thicknesses of selected hydrogeologic units of the Floridan aquifer system were developed to define an updated hydrogeologic framework as part of the U.S. Geological Survey Groundwater Resources Program. The dataset contains structural surfaces depicting the top and base of the aquifer system, its major and minor hydrogeologic units and zones, geophysical marker horizons, and the altitude of the 10,000-milligram-per-liter total dissolved solids boundary that defines the approximate fresh and saline parts of the aquifer system. The thicknesses of selected major and minor units or zones were determined by interpolating points of known thickness or from raster surface subtraction of the structural surfaces. Additional data contained include clipping polygons; regional polygon features that represent geologic or hydrogeologic aspects of the aquifers and the minor units or zones; data points used in the interpolation; and polygon and line features that represent faults, boundaries, and other features in the aquifer system.

\section{Introduction}

In the fall of 2009 the U.S. Geological Survey (USGS) began a regional study of groundwater resources of the Floridan aquifer system as part of a national assessment conducted through the Groundwater Resource Program (GWRP). A major goal of these studies is to provide updated information about the current status of groundwater resources in principal aquifers and to develop tools and datasets to assist State, county, municipal agencies, as well as those of special districts formed for water-resources management, for making long-term groundwater management decisions (Reilly and others, 2008).

\section{Purpose and Scope}

The purpose of this report is to provide a georeferenced digital dataset for the revised hydrogeologic framework of the Floridan aquifer system developed for the ongoing study of groundwater availability, described in more detail in Williams and Kuniansky (2015). The dataset contains structural surfaces depicting the top and base of the aquifer system, its major and minor hydrogeologic or lithostratigraphic composite units and zones, geophysical marker horizons, and the altitude of the 10,000-milligram-per-liter ( $\mathrm{mg} / \mathrm{L}$ ) total dissolved solids (TDS) boundary that defines the approximate fresh and saline parts of the aquifer system (appendix 1). Thicknesses of selected major and minor units or zones within the Upper and Lower Floridan aquifer system were developed by interpolating points of known thickness or by using geographic information system (GIS) tools to subtract raster surfaces contained in the dataset (herein called raster surface subtraction). Additional feature classes included in the dataset are polygons of hydrogeologic unit extents, regional polygon features that represent geologic or hydrogeologic aspects of the aquifers and the minor units or zones, data points used in the interpolation and polygon and line features that represent faults, boundaries, and other features in the aquifer system.

The dataset is provided in several downloadable compressed archives available from the USGS Web page for this report (http://pubs.er.usgs.gov/publication/ds926). The data are contained in both Esri ArcGIS and open-file formats as vector and raster data. Vector data (point, line, and polygon), also referred to herein as feature classes, are a collection of geographic features having the same geometry, attributes, and spatial reference; contour lines and clipping polygons are examples of feature classes included in the dataset. Raster data (herein referred to as rasters) are in a data format consisting of an array of equally sized cells arranged in rows and columns of a matrix. Rasters are used to represent 
continuous interpolated surfaces of hydrogeologic tops and thicknesses of units. ArcGIS version 9 was used in the creation of contour lines and rasters from point values, herein, thus changes to software in future versions of ArcGIS may result in slight differences in developing raster surfaces or contour lines from point data.

\section{Sources of Data and Key Well Locations}

Data collected from over 5,000 wells were used in the development of the revised hydrogeologic framework, including geophysical or lithologic logs from approximately 900 key wells, which were the primary source of information used to correlate major and minor hydrogeologic units (fig. 1). Data from these wells were obtained from numerous sources over a period of 2 years. Files containing the original correlation geophysical logs and lithologic descriptions used in the development of the hydrogeologic framework by Miller (1986) were initially used to evaluate geophysical log responses across the previously mapped units and for correlation to newer geophysical logs. Additional logs and data were then obtained from the South Florida Water Management District DBHYDRO database (http://www.sfwmd.gov/ dbhydroplsql/show_dbkey_info.main_menu), St. Johns River Water Management District, and Southwest Florida Water Management District. In addition to these sources of data, digital well completion information and a limited number of geophysical logs were obtained from the Suwannee River Water Management District and Northwest Florida Water Management District. Geophysical logs and other data were scanned from paper files of the USGS Orlando, Ft. Lauderdale, Tampa, and Tallahassee offices in Florida, and the Atlanta offices in Georgia, and from files of the Florida Geological Survey, Geologic Survey of Alabama, and Georgia Environmental Protection Division.

\section{Well Numbering System and Control Points}

Wells used to construct the revised hydrogeologic framework were denoted with unique well identifiers (UWI) used throughout the dataset. Previously assigned well identifiers of Miller (1986) were updated to the State permit numbers or local identifiers wherever possible. Permitted oil and gas test wells were identified using State-assigned permit numbers. In Florida, permitted oil and gas test wells were denoted with a "P" prefix followed by the associated permit number (P1, for example). In Georgia, permitted oil and gas logs were denoted with a "GGS" prefix followed by the number assigned by the Georgia Geological Survey (GGS3114, for example). A few oil and gas test wells in Georgia that do not have an assigned GGS number were denoted with a "DP" prefix followed by the Georgia Environmental Protection Division permit number. In Alabama, permitted oil and gas test wells were denoted an "AP" prefix followed by the permit number (AP1111, for example). Deep test wells drilled for water-related investigations were identified using previously assigned water management district or State geologic survey identifiers. The uniqueness of each UWI was verified across the database to avoid duplication.

Control points also are contained in the database and were mostly used in aquifer outcrop areas where the hydrogeologic surfaces needed to be constrained to land surface or where thin units are dissected by streams. The control points are identified using a " $u$ " flag designation in data tables contained in the dataset. Many of the geophysical logs utilized were published in Williams and others (2013).

\section{Description of Study Area}

The Floridan aquifer system underlies an area of about 100,000 square miles $\left(\mathrm{mi}^{2}\right)$ in the southeastern United States, including all of Florida and parts of Georgia, Alabama, and South Carolina (fig. 1). The Floridan is one of the principal aquifer systems of the United States and supplies much of the freshwater for all uses in the study area, except in extreme southern Florida and in the western Florida panhandle where the surficial aquifer system is principally used (Miller, 1986; Renken, 1996). The Floridan comprises a highly productive sequence of mostly Tertiary age carbonate rocks, including the Suwannee Limestone, Ocala Limestone, Avon Park Formation, and Oldsmar Formation, that are hydraulically connected to varying degrees (Miller, 1986). Many other deeper formations also are included in the Floridan depending on the area of consideration and degree of hydraulic connection of these rocks to the main carbonate rock system (fig. 2). The aquifer system is overlain by a thick sequence of clastic sediments and fine-grained low-permeability limestone, mostly of the Hawthorn Group of middle Miocene age, which forms its upper confining unit (UCU). The presence or absence of UCU changes the Floridan from fully confined to unconfined over short distances and is the principal control on the recharge and discharge patterns developed within the aquifer system.

Coastal Plain deposits in the study area are generally grouped into two principal facies: (1) predominantly warm, shallow marine, platform carbonate rocks that have been deposited in a thick continuous sequence beneath southeastern Georgia and the Florida peninsula and (2) predominantly clastic rocks that have been deposited in the Coastal Plain extending from the Fall Line (fig. 1) southward and eastward toward the Gulf of Mexico and Atlantic Ocean. These two major facies are respectively divided into the mostly carbonate Floridan aquifer system and the mostly clastic Southeastern Coastal Plain aquifer system (fig. 2).

Because of the gradational nature of the carbonate-clastic sequence, some of the updip clastic aquifers are included in the Floridan aquifer system, Southeastern Coastal Plain aquifer system, or both, as needed to portray the major elements of the groundwater-flow system being modeled or studied (Barker and Pernik, 1994; Bush and Johnston, 


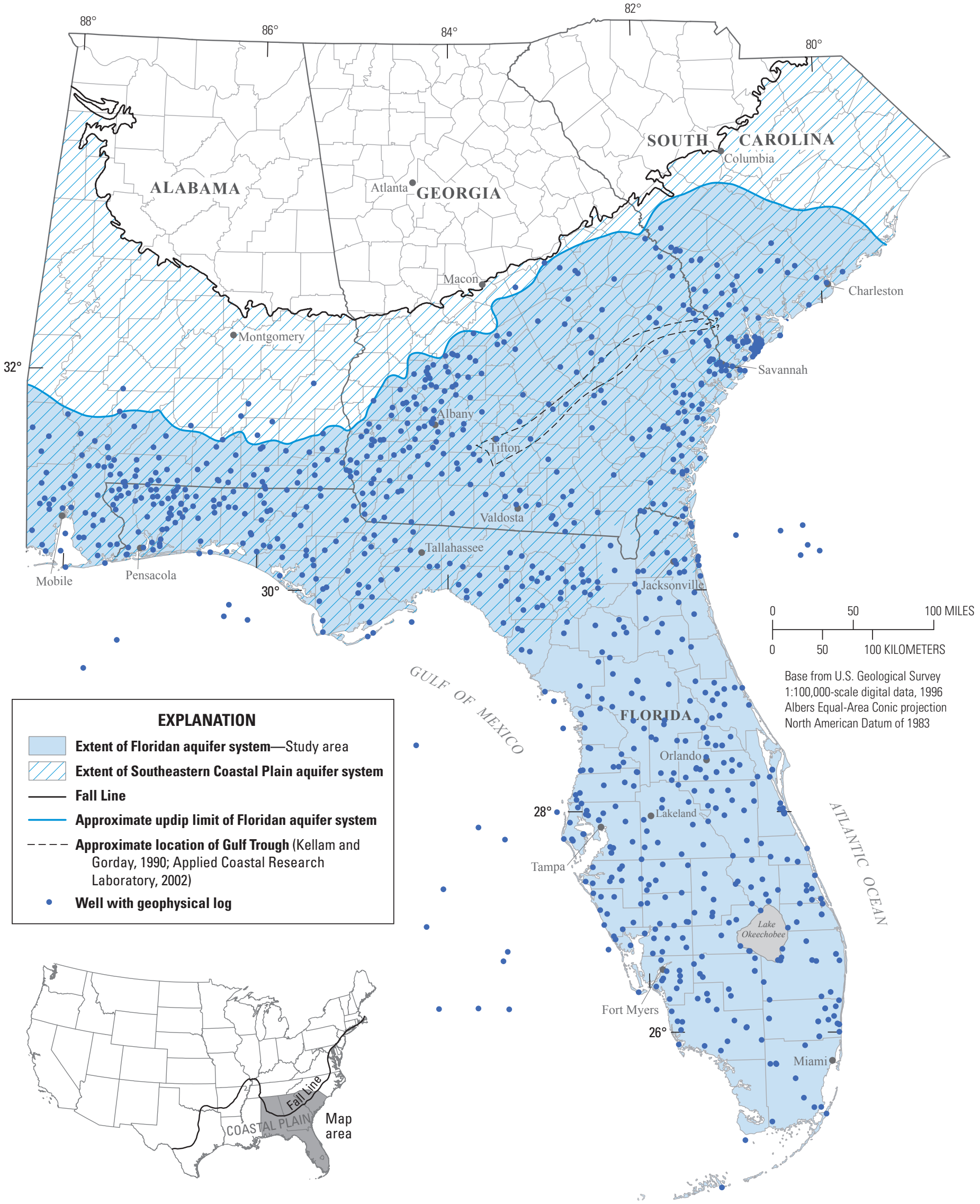

Figure 1. Study area location map showing extent of the Floridan and Southeastern Coastal Plain aquifer systems and location of key wells (modified from Williams and Kuniansky, 2015). 

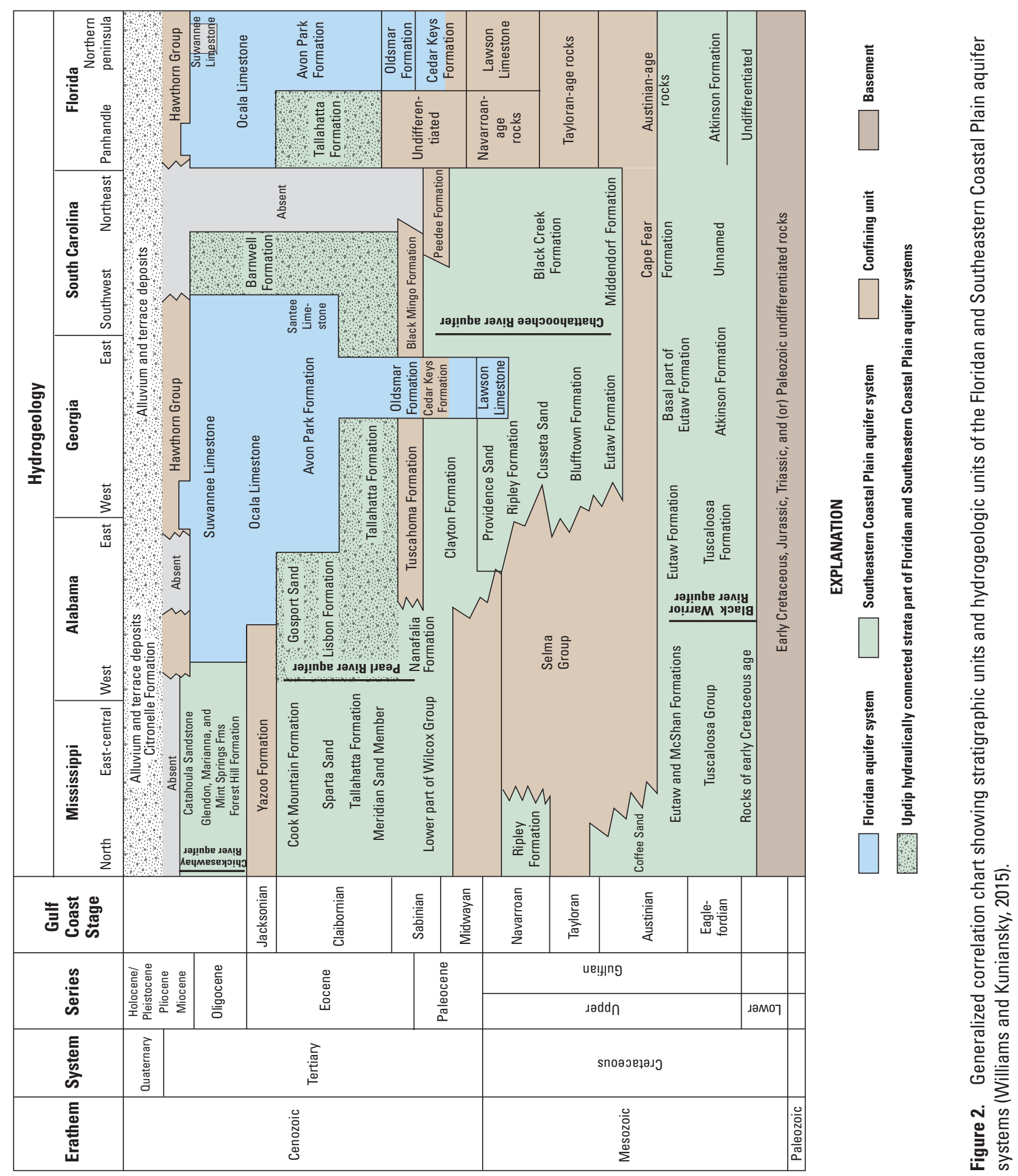
1988; Campbell and Coes, 2010; Krause and Randolph, 1989; Maslia and Hayes, 1988; Payne and others, 2005). The Claiborne aquifer (McFadden and Perriello, 1983), Gordon aquifer (Brooks and others, 1985), and Lisbon aquifer (Gillett and others, 2004) are part of the regional Pearl River aquifer of the Southeastern Coastal Plain aquifer system (Renken, 1996) and are less permeable than the carbonate rocks of the Floridan aquifer system and grade laterally into the Lower Floridan aquifer. The Lisbon, Claiborne, and Gordon aquifers are shown on the correlation chart in figure 2 .

\section{Methods}

Structural surfaces and thicknesses of hydrogeologic units were interpolated from scattered data points compiled mostly from correlation of geophysical and lithologic logs and data from published reports. Log measuring points were determined from information provided in the log header, digital elevation models (DEMs), the USGS National Water Information System (http://waterdata.usgs.gov/nwis/), or from digital data provided by State agencies. The depth to the top of each hydrogeologic unit was determined mostly by correlating known geophysical log response or from lithologic and available paleontological reports. Altitudes of hydrogeologic units were calculated by subtracting the depth to the top of the unit determined on the geophysical or lithologic log from the measuring point. All of the structural surfaces and two of the thickness rasters were interpolated from scattered data points using the Australian National University Digital Elevation Model method on a 1,000×1,000-meter (m) grid (Hutchinson, 1988, 1989) as implemented in ArcGIS version 9. This method can produce areas higher or lower than the data point because local trends are taken into account during the interpolation process.

The differences between actual and interpolated values determined using the Australian National University Digital Elevation Model method are summarized in table 1. Minimum and maximum residuals were mainly located in the outcrop areas of the aquifer and around features such as the Gulf Trough in Georgia where abrupt changes in altitude over short distances caused some higher minimum and maximum differences as a result of the averaging of values that occurs across $1,000 \times 1,000-\mathrm{m}$ grid cells. Actual values within 5 feet (ft) of the corresponding interpolated digital hydrogeologic surface ranged from 77 to 97 percent of the total number of values for all surfaces (fig. 3).

Table 1. Summary statistics showing difference between actual and interpolated altitudes and thickness of hydrogeologic units and surfaces.

[Count refers to the number of data points used in comparing actual and interpolated values. Mean, minimum, maximum, and absolute mean error are statistical measures between the actual and interpolated values. Positive numbers indicate interpolated value is greater than actual value and negative numbers indicate interpolated value is less than actual value. $\mathrm{mg} / \mathrm{L}$, milligrams per liter]

\begin{tabular}{|c|c|c|c|c|c|}
\hline Top of hydrogeologic unit or thickness & Count & $\begin{array}{l}\text { Minimum } \\
\text { difference } \\
\text { (feet) }\end{array}$ & $\begin{array}{c}\text { Maximum } \\
\text { difference } \\
\text { (feet) }\end{array}$ & $\begin{array}{l}\text { Mean } \\
\text { difference } \\
\text { (feet) }\end{array}$ & $\begin{array}{c}\text { Mean } \\
\text { absolute } \\
\text { error } \\
\text { (feet) }\end{array}$ \\
\hline Top of Ocala-Avon Park lower-permeability zone & 143 & -9.29 & 31.44 & 0.27 & 1.58 \\
\hline Top of Avon Park permeable zone (aggregated) & 144 & -18.29 & 13.76 & 0.017 & 2.13 \\
\hline Top of middle Avon Park composite unit & 240 & -75.42 & 17.61 & -0.59 & 2.29 \\
\hline $\begin{array}{l}\text { Top of regional surface that defines base of Upper Floridan } \\
\text { aquifer (top of middle confining and composite units) }\end{array}$ & 780 & -119.49 & 70.8 & -2.36 & 5.24 \\
\hline Top of Bucatunna clay confining unit & 142 & -79.48 & 63.88 & -0.95 & 5.41 \\
\hline Top of regional Lower Floridan aquifer & 778 & -120 & 84.72 & -2.55 & 7.3 \\
\hline Top of Oldsmar permeable zone (OLDSPZ) & 174 & -21.27 & 26.83 & -0.22 & 1.97 \\
\hline Top of low resistivity zone below OLDSPZ & 156 & -21.52 & 33.79 & 0.007 & 2.6 \\
\hline Top of base of Floridan aquifer system & 469 & -42.77 & 40.83 & -0.16 & 4.04 \\
\hline Top of $10,000-\mathrm{mg} / \mathrm{L}$ total dissolved solids boundary & 561 & -166.28 & 181.14 & 0.4 & 6.01 \\
\hline Thickness of surficial materials & 5,227 & -261.74 & 304.4 & -0.41 & 3.77 \\
\hline Thickness of the upper confining unit & 4,196 & -135.91 & 266.45 & -0.37 & 7.19 \\
\hline
\end{tabular}



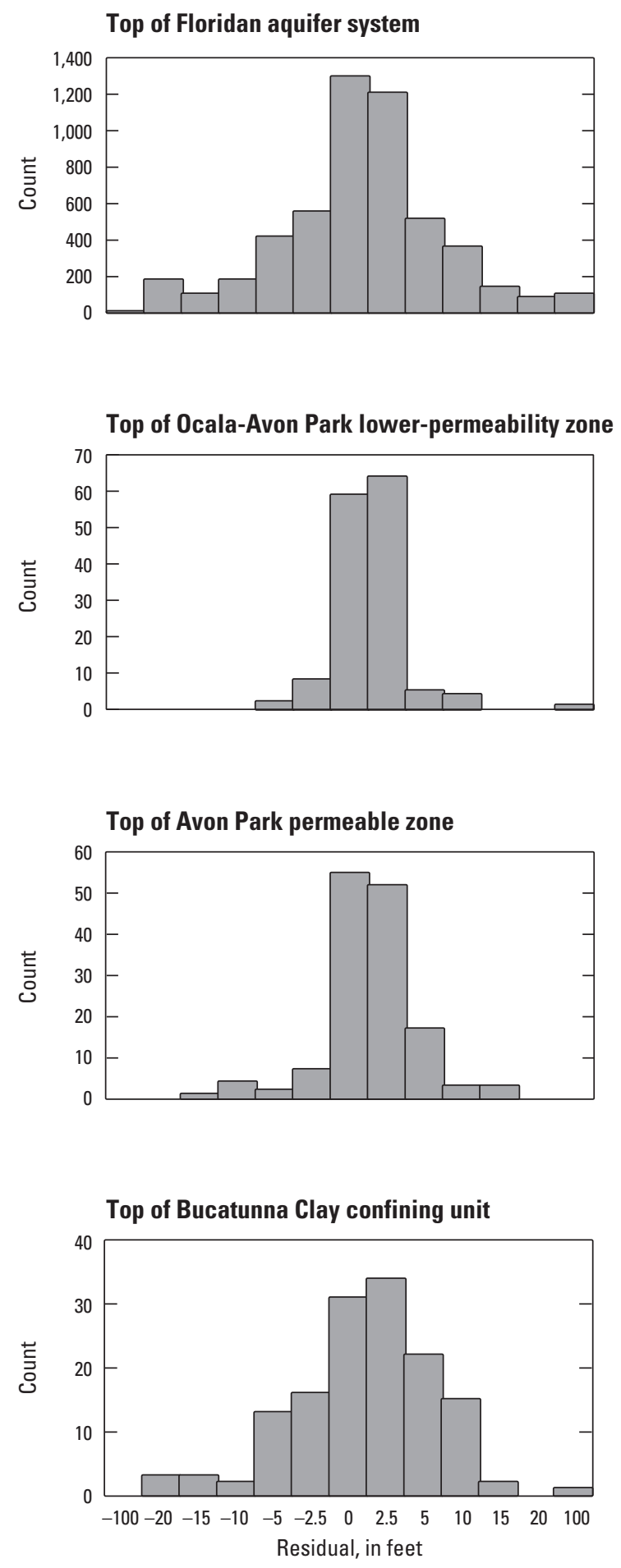
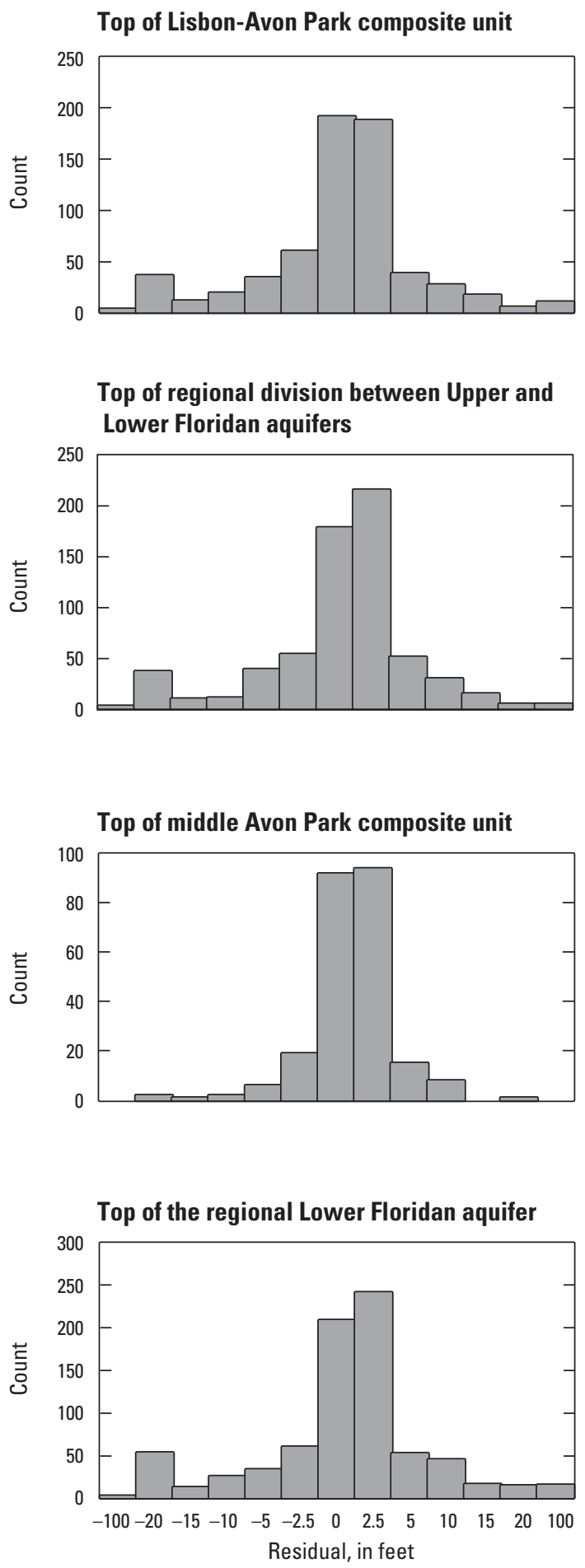

Figure 3. Histograms of residuals between actual hydrogeologic unit altitudes determined on well logs and altitudes of the interpolated hydrogeologic surface. 
Top of Lower Floridan aquifer below Lisbon-Avon Park composite unit
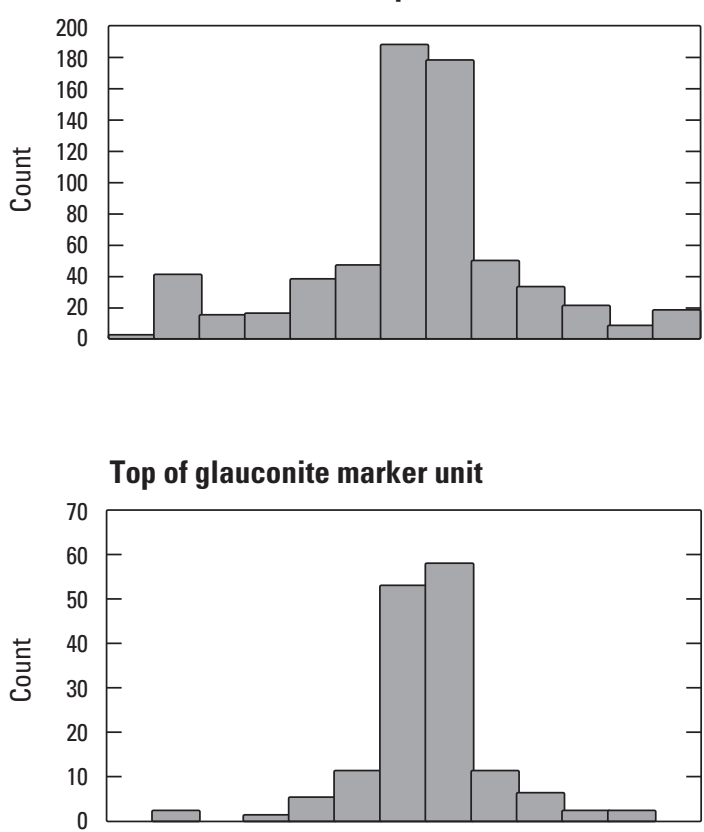

Top of low-resistivity zone below Oldsmar permeable zone

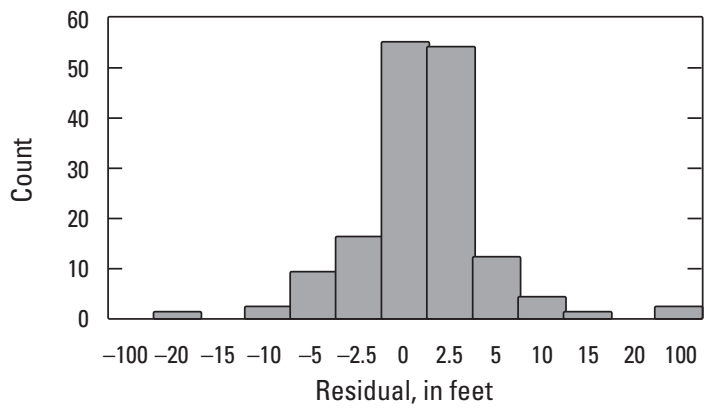

Top of the lower Avon Park permeable zone

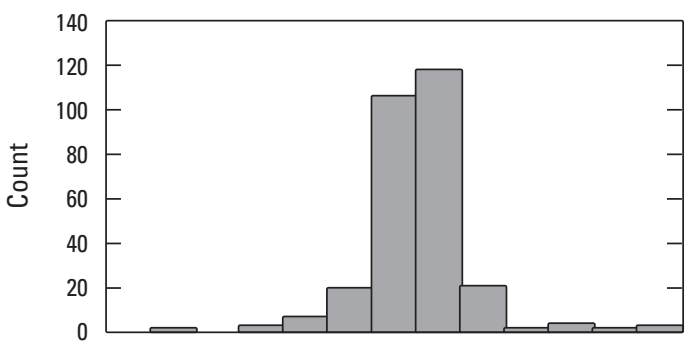

Top of Oldsmar permeable zone
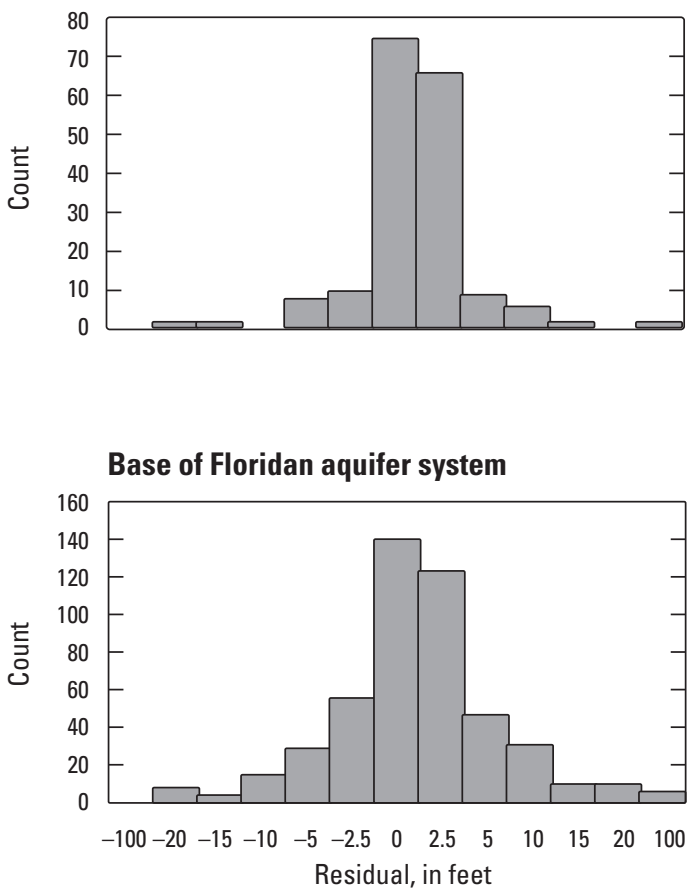

Figure 3. Histogram of residuals between actual hydrogeologic unit altitudes determined on well logs and altitudes of the interpolated hydrogeologic surface.-Continued 
In the outcrop areas of the Floridan aquifer system, it was necessary to constrain some of the interpolated hydrogeologic surfaces to prevent them from inadvertently rising above land surface. To accomplish this, the top of the aquifer system was first interpolated using scattered data points without control to produce an unconstrained raster surface. This surface was then compared to the land surface DEM and reclassified to identify cells having altitudes above land surface. Using these cells as control points, the top of the Floridan was re-interpolated, setting the altitude of these cells equal to land surface altitude (minus any overlying materials). Subsequently, each of the underlying units was constrained to its overlying unit. To preserve thickness of each unit in the outcrop area, the altitude of the top of each successively deeper unit was set to a minimum of $10 \mathrm{ft}$ below the overlying hydrogeologic surface. Although this approach does not produce erosional pinch-out of the units, as would be expected in some of the outcropping areas, a minimal thickness for each unit is maintained.

Thickness rasters were constructed by either using interpolation of scattered data points or surface subtraction as needed for the presentation in this report. For the surficial aquifer system and UCU, interpolation of scattered data points was used to depict the thickness of each of these units, rather than the top and bottom of each, primarily because the discontinuous nature of one or both of these units in many parts of the study area precluded explicit interpolation of their top and bottom surfaces. By using interpolation, the surficial aquifer system and UCU were essentially treated as a depositional "blanket" (over the Floridan aquifer system) whose thickness was based on scattered data points and supplemented by additional control points to delineate where these units pinch out. Interpolation also was necessary to estimate the thickness of the Floridan aquifer system and thickness of the Upper Floridan aquifer because of the large disparity between the number of data points representing the top (approximately 4,200 ) and base (approximately 700) of the aquifer system.

Raster surface subtraction was used for most of the remaining units of the system. These units had extents that could be "paired" together for subtraction and generally had approximately equal numbers of points representing the top and bottom of the units. The subtraction of two unit surfaces produces thicknesses that are consistent with the interpreted altitudes of the corresponding overlying and underlying digital surfaces. Thickness could not be estimated by subtraction in areas where paired surfaces did not overlap.

The hydrogeologic surfaces and thickness rasters presented in this dataset represent a continuous grid of interpolated values intended for regional-scale applications. The gridded data values may be limited for local-scale use resulting from areas of sparse well control, inaccurate log datums, uncertain hydrogeologic unit extents, interpolation limitations, and the size of the grid cell and averaging over the area of the cell. Data control points are included in the dataset so that other interpolation approaches and finer grid-cell sizes can be used if needed for future applications.

\section{Digital Surfaces and Thicknesses of Hydrogeologic Units}

The two major groundwater flow systems in the study area include the surficial aquifer system and the Floridan aquifer system. These systems interact with each other to varying degrees and are separated over much of their extent by the low-permeability sequence of clastic sediments known as the UCU of the Floridan aquifer system. The Floridan is underlain everywhere by low-permeability rocks called the lower confining unit, which separates high-permeability rocks of the Floridan aquifer system from older, deeper aquifers of the Southeastern Coastal Plain aquifer system.

The Floridan aquifer system can be progressively divided from more generalized regional units that cover the entire aquifer system into more detailed, thinner hydrogeologic zones of subregional extent (fig. 4). This report provides digital surfaces, for both the regional and subregional units, that can be used to represent the interpolated geometry of the aquifer system.

Regionally, the Floridan aquifer system is divided into two aquifers: the Upper Floridan aquifer, which consists of the uppermost permeable zone of the aquifer system, and the Lower Floridan aquifer, which consists of the lowermost permeable zones of the aquifer system and includes the largest part of the brackish- and saline-water system. Zones of higher and lower permeability have been mapped within both aquifers (Williams and Kuniansky, 2014) and represent localized or subregional areas where hydraulic properties are substantially higher or lower than the bulk properties of the aquifer unit in which they are contained.

The Upper and Lower Floridan aquifers are separated by discontinuous overlapping lithostratigraphic and hydrogeologic units of subregional extent. From top to bottom, these units are the Bucatunna clay confining unit, the Lisbon-Avon Park composite unit, and the middle Avon Park composite unit. The hydrogeologic framework and constituent units and zones of the Floridan aquifer system are described in more detail in Williams and Kuniansky (2015).

\section{GIS Formats Used for the Digital Dataset}

GIS software (ArcGIS 10.1) was used to construct digital raster surfaces representing the tops of major and minor hydrogeologic units in the Floridan aquifer system. In addition, GIS was used to generate a number of thickness rasters, structural contours, faults, extent polygons, and point features.

This dataset is downloadable as a series of compressed archives with the data contained in several different formats. The ds926.gdb.zip archive contains an Esri 10.1 file geodatabase composed of point, line, and polygon feature classes in addition to the rasterized structural surfaces. Because ArcGIS software is required to open and read the Esri 10.1 file geodatabase, the data also are provided in 


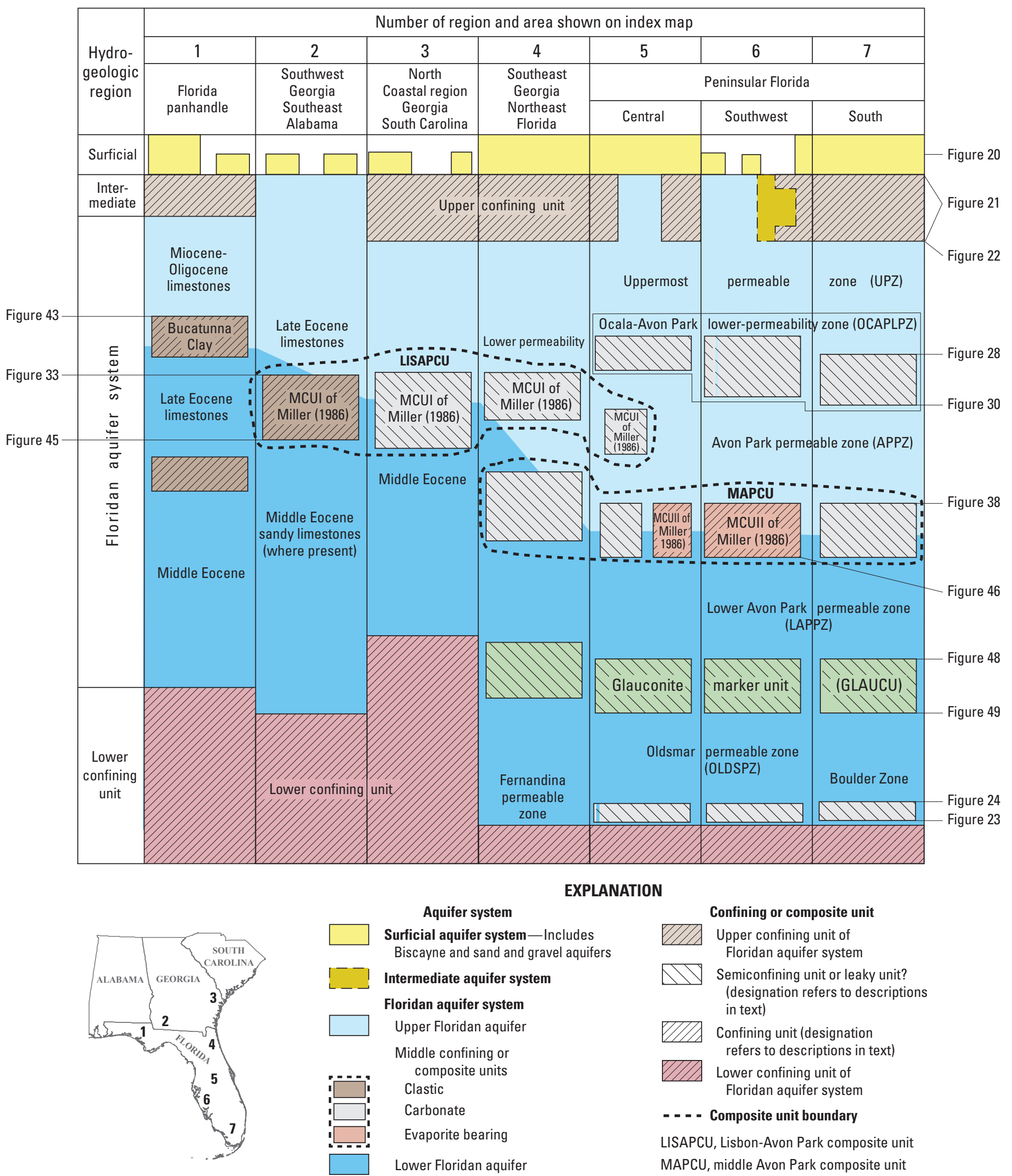

Figure 4. Schematic cross section showing regional and subregional aquifers, composite units, and confining units of the Floridan aquifer system (Williams and Kuniansky, 2015). 
Esri shapefile and American Standard Code for Information Interchange (ASCII) formats that can be read by a wide variety of GIS systems. The compressed archive ds926_shapefiles.zip is a subset of the file geodatabase and contains all of the vector (point, line, and polygon) features in the Esri shapefile format. The compressed archive ds926_ASCII_rasters.zip contains the digital structural and thickness rasters in a plain ASCII format.

All geospatial datasets use a custom Albers Conical Equal Area projection with standard parallels and central meridian for the study area as follows; North American Datum of 1983, standard parallels at 29.5 and 45.5 degrees, and central meridian at -84 degrees.

\section{Organization of Dataset}

The feature classes in this dataset are mostly organized by figure number used in the companion report (Williams and Kuniansky, 2015). During the review process, some of the original figure numbers were changed and the current figure number from Williams and Kuniansky (2015) is correctly noted on figure 4 herein, but not all figure numbers included in the filenames are correct. Within the dataset, structural surfaces and thickness figures are represented by at least three feature classes, including contour, point, and a gridded raster surface. Features that appear on multiple figures, such as the Gulf Trough, faults, and aquifer boundary lines, are placed in the other features dataset. Polygon feature classes used to clip rasters and contour lines to the desired extent of the hydrogeologic unit are included in the dataset. The clipping polygons, however, may not necessarily represent the full extent of the unit in offshore areas. Clipping boundaries were drawn on the basis of data availability and usually were extended several miles offshore.

A complete list of the contents of the Floridan aquifer system framework geodatabase is provided in the appendix. An abbreviated naming convention was used in the dataset. The general format is a multipart name first identifying the figure or plate number, followed by descriptive hydrogeologic unit indicators, and ending with the nature of the data. The last part of the feature name describes the general nature of the feature, including terms such as "contours" (vectorized contour lines), "extent" (generalized clipping polygon), "pts" (point data used for contouring), and "raster" (gridded raster surface). Additional conventions used in the dataset include features containing phrases such as "saline_areas" (generalized polygon regions depicting the area of the hydrogeologic unit estimated to contain greater than $10,000 \mathrm{mg} / \mathrm{L}$ of TDS), "head_diff_wells" (wells used to calculate head differences across lower-permeability units), "regions" (polygon regions depicting different areas of a composite unit that has different hydraulic properties), and "geo_units" (polygon regions depicting the rock-stratigraphic unit at the top of the hydrogeologic unit). This report also includes thickness rasters and other features not presented in Williams and Kuniansky (2015).

\section{Surficial Aquifer System}

Post-Miocene deposits in the study area can generally be grouped into three units. From oldest to youngest, these are (1) marginal marine to shallow marine sand, clay, and limestone mostly of Pliocene age; (2) sandy, locally shelly and carbonaceous marine terrace deposits of mostly Pleistocene age; and (3) fluvial sand, gravel and (or) residuum of Holocene age. Collectively, the permeable beds of these three subdivisions are included in the surficial aquifer system. Parts of the post-Miocene sequence have been given aquifer names in places where they yield large volumes of groundwater. These local-to-subregional aquifers include the sand and gravel aquifer in the western Florida panhandle (Hayes and Barr, 1983) and the lower Tamiami (Shoemaker and Edwards, 2003), grey limestone (Reese and Cunningham, 2000), and Biscayne aquifers (Fish and Stewart, 1991) in southern Florida.

The thickness raster for the surficial aquifer system was constructed from approximately 5,200 data points and an additional 1,400 control points. Thickness values were determined from lithologic logs, geophysical logs, or both. The Florida Aquifer Vulnerability Assessment dataset (Arthur and others, 2007), and Southwest Florida Water Management District dataset (Arthur and others, 2008) were major sources of information used. In addition, a large number of control points were provided by the St. Johns River Water Management District, and additional points were obtained from the South Florida Water Management District DBHYDRO database. Thickness rasters and related features of the surficial aquifer system are listed in table 2 .

Residuum thickness in southwestern Georgia and southeastern Alabama was calculated by subtracting the top of the Floridan aquifer system from a land surface DEM. The resultant raster (table 2) provides an estimate of the thickness of weathered limestone residuum formed above the top of the aquifer system. Because this raster was constructed by surface subtraction, the estimated thickness may also include any overlying alluvium or surficial deposits. The residuum thickness raster was clipped to an extent polygon (table 2), which is the estimated area of residuum determined from (1) geologic maps and (2) information obtained from area wells and test borings. 


\section{Upper Confining Unit}

Low-permeability deposits of Miocene age underlie most of the study area, except for a fairly wide band in central and northwestern peninsular Florida and southwestern Georgia where they have been eroded away. The thickest and most extensive Miocene unit in the study area is the Hawthorn Group (fig. 2), discussed further in Scott $(1988,1990)$. In general, the Hawthorn composes a thick, generally clastic, highly variable sequence of low-permeability rock that, where present, is considered to be the UCU of the Floridan aquifer system and is identified as the intermediate confining unit (ICU) in Florida. Locally, permeable beds of the Hawthorn are included in the intermediate aquifer system (IAS) in Florida (Knochenmus, 2006; Miller, 1990) and the Brunswick aquifer system in Georgia (Clarke and others, 1990).

The thickness raster for the UCU (table 2) was interpolated using data from approximately 4,600 wells. The data points used in the interpolation were obtained from the same sources listed earlier for the surficial aquifer system. To indicate the relative degree of confinement of the Floridan aquifer system, the UCU thickness raster was classified into three polygon regions: (1) confined areas more than $100 \mathrm{ft}$ thick, (2) thinly confined areas less than $100 \mathrm{ft}$ thick, and (3) unconfined areas where the UCU is absent (table 2).

Table 2. Thickness rasters and other related features for the surficial aquifer system and upper confining unit.

[UCU, upper confining unit; IAS, intermediate aquifer system; ICU, intermediate confining unit]

\begin{tabular}{|c|c|c|}
\hline Feature class ${ }^{1}$ & Type & Description \\
\hline fig16_thickness_Surficial_raster ${ }^{2}$ & Thickness & Thickness of undifferentiated surficial materials above the UCU \\
\hline fig16_Biscayne_aquifer & Extent polygon & Extent of the Biscayne aquifer \\
\hline fig16_Sand_and_gravel_aquifer & Extent polygon & Extent of the sand and gravel aquifer \\
\hline thickness_residuum_ss ${ }^{3}$ & Thickness & Thickness of residuum overlying limestone in outcrop areas \\
\hline residuum_extent & Extent polygon & $\begin{array}{l}\text { Extent of areas that have weathered limestone residuum overlying } \\
\text { the Floridan aquifer system }\end{array}$ \\
\hline plate3_thickness_UCU_raster ${ }^{2,4}$ & Thickness & Thickness of the UCU \\
\hline plate3_thickness_UCU_regions ${ }^{4}$ & Extent polygon & Polygon regions of the UCU based on thickness \\
\hline ucu_extent_poly ${ }^{4}$ & Extent polygon & Generalized extent of the UCU \\
\hline fig17_IAS_ICU_permeable_zone_extent & Extent line & Extent of permeable beds within the UCU \\
\hline
\end{tabular}

${ }^{1}$ Feature class name is that listed for geodatabase. Point and contour features not listed.

${ }^{2}$ Derived by interpolating thickness at individual data points.

${ }^{3}$ Derived by subtracting the top of the Floridan aquifer system from land surface digital elevation model.

${ }^{4}$ Includes the ICU and IAS in Florida. 


\section{Digital Surfaces and Thicknesses of Selected Hydrogeologic Units of the Floridan Aquifer System}

\section{Top of the Floridan Aquifer System}

The top of the Floridan aquifer system is indicated by the start of a vertically continuous sequence of permeable carbonate rocks beneath the UCU or surficial aquifer system. Although high permeability is the major criterion established by Miller (1986) to indicate the top of the Floridan, in practice, either a distinct change in water level in the drilling annulus or an increase in artesian flow is commonly used to identify the top of permeable strata. By using permeability as the criterion, lower-permeability carbonate rocks at the top of the Floridan are commonly excluded from the aquifer system, even though these rocks may have some hydraulic connection to it. The geologic units forming the top of the aquifer system are depicted using a polygon feature class (table 3 ).
The structural surface representing the top of the Floridan aquifer system (table 3) was constructed using data from approximately 5,200 wells. In addition to these data points, control points were also used to constrain the top of the aquifer to land surface in outcrop areas where necessary. A polygon (fas_general_area_poly) was used to clip the raster surface and contours to the updip extent and along coastlines. Because few offshore points were available, the surface was clipped to the State coastline boundaries even though the Floridan extends offshore. A more extensive surface could be generated by including the sparse data points provided in the dataset that lie beyond the current extent of the surface; however, additional control points may be necessary constrain the surface to the seafloor and other hydrogeologic surfaces.

Table 3. Structural and thickness rasters for the Upper Floridan aquifer.

[FAS, Floridan aquifer system; UF, Upper Floridan aquifer; UPZ, uppermost permeable zone; OCAPLPZ, Ocala-Avon Park lower-permeability zone; APPZ, Avon Park permeable zone; MAPCU, middle Avon-Park confining unit]

\begin{tabular}{lll}
\multicolumn{1}{c}{ Feature class ${ }^{1}$} & \multicolumn{1}{c}{ Type } & \multicolumn{1}{c}{ Description } \\
\hline fig19_top_FAS_raster & Structural & Top of FAS, UF, and UPZ \\
fig19_top_FAS_geologic_units & Extent polygon & Extent of geologic units forming top of FAS \\
fas_general_area_poly & Extent polygon & Used for clipping, shows the general extent of system \\
fig28_top_OCAPLPZ_raster & Structural & Top of the OCAPLPZ (base of UPZ) \\
thickness_OCAPLPZ_raster_ss ${ }^{2}$ & Thickness & Thickness of the OCAPLPZ \\
fig30_top_APPZ_raster & Structural & Top of the APPZ (base of OCAPLPZ) \\
thickness_APPZ_raster_ss ${ }^{3}$ & Thickness & Thickness of the APPZ \\
fig38_top_MAPCU_raster & Structural & Top of the MAPCU (base of APPZ) \\
fig38_top_MAPCU_regions & Extent polygon & Extent of units forming the MAPCU \\
mcu_regional_raster & Structural & Base of the UF \\
fig32_thickness_UF_raster & Thickness & Thickness of the UF \\
\hline
\end{tabular}

${ }^{1}$ Feature class name is that listed for geodatabase. Point and contour features not listed.

${ }^{2}$ Derived by subtracting top of OCAPLPZ from top of FAS.

${ }^{3}$ Derived by subtracting top of MAPCU from top of APPZ. 


\section{Upper Floridan Aquifer}

The Upper Floridan aquifer includes the uppermost or shallowest permeable zones in the Floridan aquifer system. In the northern half of the study area, this aquifer is generally treated as a single hydrogeologic unit and is the undifferentiated part of the Upper Floridan aquifer. In the southern half, including most of central and southern Florida, the Upper Floridan aquifer can be differentiated into three distinct hydrogeologic units, namely the

- uppermost permeable zone (UPZ),

- Ocala-Avon Park lower-permeability zone (OCAPLPZ), and

- Avon Park permeable zone (APPZ).

The structural surfaces for the UPZ, OCAPLPZ, and the APPZ are generally contiguous in their extent and were constructed as a series of paired surfaces where the base of each overlying unit is the top of the next deeper unit (table 3). The UPZ includes the Suwannee permeable zone (Hutchinson, 1992) and permeable zones in the basal part of the Arcadia Formation and within an unnamed limestone of Oligocene age (Reese and Richardson, 2008).

The OCAPLPZ forms a subregional leaky zone within the Upper Floridan aquifer that directly underlies the uppermost permeable zone. The OCAPLPZ includes fine-grained, less-permeable carbonate rocks mostly within the Ocala Limestone in southwestern Florida, where it has been called the lower-Suwannee-Ocala semiconfining unit (Hutchinson, 1992), the Ocala semi-confiner (Clayton and McQuown, 1994), and the Ocala low-permeability zone (LaRoche, 2007). The OCAPLPZ also includes relatively less-permeable carbonate rocks in the upper part of the Avon Park Formation in southeastern Florida within MCUI of Miller (1986) and the "semiconfining unit" of Lukasiewicz (1992). Reese and Richardson (2008, p. 30) mapped the OCAPLPZ as a leaky unit above the APPZ and called it "MC1" in southern Florida. The term "lower-permeability" used herein for the
OCAPLPZ is not established in the literature; however, the carbonates of the OCAPLPZ are not low in permeability (the hydraulic conductivity is not less than $10^{-3}$ feet per day [ft/d] and often greater than $10 \mathrm{ft} / \mathrm{d}$ ) but several orders of magnitude less permeable than the cavernous or preferential flow zones within the Upper Floridan aquifer. Reese and Richardson (2008, p. 30, fig. 13) mapped it as an extensive hydrogeologic unit above the APPZ and called it "MC1" of the middle confining unit.

The APPZ (Reese and Richardson, 2008) is a highly permeable zone in central and southern Florida that is mapped overlying relatively thick beds of permeable fractured and cavernous dolostone including beds of relatively lower permeability limestone, dolomitic limestone, and dolostone. The structural surface representing the top of the APPZ (table 3) was redefined in this study to include all highly permeable and less permeable rock between the underlying middle Avon Park composite unit and overlying OCAPLPZ. The redefined unit, informally called the "aggregated Avon Park permeable zone," represents several permeable zones grouped into a single hydrogeologic unit of the Upper Floridan aquifer.

Regionally, the Upper Floridan aquifer is defined and bounded by two raster surfaces in the dataset. The top of the Upper Floridan aquifer is represented by the top of the Floridan aquifer system raster surface, which was developed using data points representing the top of the vertically continuous carbonate rock section or in unconfined areas it is the base of surficial materials overlying the carbonate rock section. The base of the Upper Floridan aquifer is represented by the top of a surface called the regional middle confining and composite unit (MCU) surface (table 3). The regional MCU represents a continuous surface developed using data points that include the middle Avon Park composite unit in peninsular Florida, Lisbon-Avon Park composite unit in northern Florida and all of Georgia, southeast Alabama, and South Carolina, and the Bucatunna clay confining unit in the western panhandle of Florida and southwest Alabama (described in the next section). The units that form the top of the regional MCU are defined with a polygon feature class (table 3 ). 


\section{Middle Confining and Composite Units}

In the approximate middle part of the Floridan aquifer system, a series of discontinuous lower-permeability units of subregional extent are utilized to divide the aquifer system into the Upper and Lower Floridan aquifers. In the revised framework (Williams and Kuniansky, 2015), the numbered, discontinuous middle confining units previously defined by Miller (1986, p. B55-B63) were substantially revised and the numbered middle confining unit terminology abandoned. Although the term "confining unit" is not totally abandoned herein and in Williams and Kuniansky (2015), a new term, "composite unit," is introduced for lithostratigraphic units that cannot be defined as either a confining or aquifer unit over its entire extent. The confining and composite units that divide the aquifer system into the Upper and Lower Floridan aquifers from shallowest to deepest are the

- Bucatunna clay confining unit,

- Lisbon-Avon Park composite unit, and

- Middle Avon Park composite unit.

Digital structural surfaces and thickness rasters for each of the three subregional units are listed in table 4 . The first two "composite units" have subregions delineated on the basis of variations in permeability and the relative degree of confinement that these units provide between the Upper and Lower Floridan aquifers. These composite units include confining material, semiconfining material, and in some areas, aquifer material that may have properties similar to those of the Upper and Lower Floridan aquifers, but are included in the litho-stratigraphic composite unit to consistently divide the aquifer system into the Upper and Lower Floridan aquifers. These raster surfaces are intended to be used in combination with an accompanying polygon feature class that depicts regional variations of relative permeability or "leakiness" (table 4). In some regions, the hydraulic properties may be well known, whereas in other areas, the hydraulic properties need to be inferred from geologic assessment of the materials that compose the unit of that region. The character of the different regions of each of the subregional middle confining and composite units are discussed further in Williams and Kuniansky (2014). The Bucatunna clay confining unit consists of a single lithostratigraphic unit and does not require polygon regions to define spatial variation in properties.

For regional representation of the "middle confining and composite unit (MCU)," the Lisbon-Avon Park composite unit, middle Avon Park composite unit, and Bucatunna clay confining unit were combined to produce the regional MCU raster (table 4). Although this surface is derived principally from each of the middle confining and composite units, it is generalized where two or more units overlap.

Table 4. Structural and thickness rasters for the middle confining and composite units of the Floridan aquifer system.

[LISAPCU, Lisbon-Avon Park composite unit; LF, Lower Floridan aquifer; MAPCU, middle Avon Park composite unit; LAPPZ, lower Avon-Park permeable zone; MCU, middle confining unit]

\begin{tabular}{lll}
\hline \multicolumn{1}{c}{ Feature class ${ }^{1}$} & \multicolumn{1}{c}{ Type } & \multicolumn{1}{c}{ Description } \\
\hline fig33_top_LISAPCU_raster & Structural & Top of the LISAPCU \\
fig45_top_LF_below_LISAPCU_raster & Structural & Top of the LF below LISAPCU (base of LISAPCU) \\
thickness_LISAPCU_raster_ss ${ }^{2}$ & Thickness & Thickness of the LISAPCU \\
fig33_top_LISAPCU_regions & Extent polygon & Regional variations of the confining unit \\
fig38_top_MAPCU_raster & Thickness & Top of the MAPCU \\
fig38_top_MAPCU_regions & Extent polygon & Regional variations of confining unit \\
thickness_MAPCU_raster_ss ${ }^{3}$ & Thickness & Thickness of the MAPCU \\
fig46_top_LAPPZ_raster & Structural & Top of the LAPPZ (base of MAPCU) \\
fig43_top_Bucatunna_raster & Structural & Top of the Bucatunna clay confining unit \\
fig43_bot_Bucatunna_raster & Structural & Base of the Bucatunna clay confining unit \\
thickness_Bucatunna_raster_ss ${ }^{4}$ & Thickness & Thickness of the Bucatunna clay confining unit \\
mcu_regional_raster & Structural & Top of the regional middle composite and confining unit surface \\
fig44_top_LF_MCU_regions & Extent polygon & Regional variations of confining unit \\
fig44_top_LF_raster & Structural & Base of the regional MCU (top of regional LF) \\
thickness_MCU_regional_raster_ss & Thickness & Thickness of the regional MCU \\
\hline
\end{tabular}

${ }^{1}$ Feature class name is that listed for geodatabase. Point and contour features not listed.

${ }^{2}$ Derived by subtracting top of the LF below LISAPCU from top of LISAPCU.

${ }^{3}$ Derived by subtracting top of LAPPZ from top of MAPCU.

${ }^{4}$ Derived by subtracting base of from top of Bucatunna clay confining unit.

${ }^{5}$ Derived by subtracting top of regional Lower Floridan aquifer from top of regional middle composite and confining unit (MCU) raster. 


\section{Lower Floridan Aquifer}

The Lower Floridan aquifer includes (1) all permeable and less-permeable zones below the middle Avon Park composite unit in peninsular Florida, (2) the Bucatunna clay confining unit in the western panhandle of Florida and contiguous areas in Alabama, and (3) the Lisbon-Avon Park composite unit in the northern part of the study area. Digital structural surfaces and thickness rasters for the Lower Floridan aquifer and its subregional units are listed in table 5.

Subregional units of the Lower Floridan aquifer include the

- undifferentiated Lower Floridan aquifer in northern part of the Floridan aquifer system, defined herein as the Lower Floridan aquifer below the Lisbon-Avon Park composite unit (LISAPCU);

- updip clastic units, namely the Lisbon, Claiborne, and Gordon aquifers, as defined by polygon regions in Alabama, Georgia, and South Carolina, respectively. These units form updip clastic-equivalent aquifers of the predominantly carbonate Lower Floridan aquifer rocks considered to be part of the Southeastern Coastal Plain aquifer system (Renken, 1996);
- Lower Floridan aquifer beneath the Bucatunna clay confining unit in the western panhandle of Florida;

- lower Avon Park permeable zone (LAPPZ) in central and southern peninsular Florida, defined by its stratigraphic position in the Avon Park Formation below major evaporite units of the middle Avon Park composite unit;

- glauconite marker unit in central and southern peninsular Florida, distinguished by relatively low permeability and a distinctive geophysical log pattern and roughly equivalent in extent to the overlying and underlying units; and the

- Oldsmar permeable zone (OLDSPZ) in central and southern peninsular Florida, distinguished by relatively high permeability and a distinctive geophysical log pattern. Cavernous zones of the OLDSPZ include the

- Boulder zone (BZ) in the southern Florida region (saline water zones), and

- Fernandina permeable zone (FPZ) in northeastern Florida and southeastern Georgia region (fresh- and saline-water zones).

Table 5. Structural and thickness rasters for the Lower Floridan aquifer.

[LF, Lower Floridan aquifer; LISAPCU, Lisbon-Avon Park composite unit; LAPPZ, lower Avon-Park permeable zone; OLDSPZ, Oldsmar permeable zone; FAS, Floridan aquifer system]

\begin{tabular}{|c|c|c|}
\hline Feature class ${ }^{1}$ & Type & Description \\
\hline fig45_top_LF_below_LISAPCU_raster & Structural & Top of the LF below LISAPCU \\
\hline fig46_top_LAPPZ_raster & Structural & Top of the LAPPZ \\
\hline fig48_top_GlaucUnit_raster & Structural & Top of the glauconite marker unit (base of LAPPZ) \\
\hline thickness_LAPPZ_raster_ss ${ }^{2}$ & Thickness & Thickness of the LAPPZ \\
\hline thickness_GlaucUnit_raster_ss ${ }^{3}$ & Thickness & Thickness of the glauconite marker unit \\
\hline fig43_bot_Bucatunna_raster & Structural & Base of the Bucatunna clay confining unit (top of LF) \\
\hline fig49_top_OLDSPZ_raster & Structural & Top of the OLDSPZ (base of GlaucUnit) \\
\hline fig21_LowResZone_below_OLDSPZ_raster & Structural & Top of the low-resistivity zone below the OLDSPZ (base of OLDSPZ) \\
\hline thickness_OLDSPZ_raster_ss ${ }^{4}$ & Thickness & Thickness of the OLDSPZ \\
\hline fig44_top_LF_raster & Structural & Top of regional LF (base of the regional middle confining unit) \\
\hline fig20_base_FAS_raster & Structural & Base of the Floridan aquifer system \\
\hline fig50_thickness_LF_raster_ss ${ }^{5}$ & Thickness & Thickness of the regional LF \\
\hline
\end{tabular}

${ }^{1}$ Feature class name is that listed for geodatabase. Point and contour features not listed.

${ }^{2}$ Derived by subtracting top of the glauconite marker unit from top of the LAPPZ.

${ }^{3}$ Derived by subtracting top of the OLDSPZ from top of the glauconite marker unit.

${ }^{4}$ Derived by subtracting top of the low-resistivity zone below the OLDSPZ from the top of the OLDSPZ.

${ }^{5}$ Derived by subtracting base of the FAS from the top of the LF. 


\section{Base of Floridan Aquifer System}

The base of the Floridan aquifer system is marked by rocks of relatively low permeability that are collectively included in the lower confining unit. The rocks that form the base of the Floridan range in age from late Eocene to late Paleocene, depending on the area considered. Similar to other hydrogeologic units of the aquifer system, many different formations and rock types were used to construct the basal surface of the Floridan. Data from 488 wells were used to construct the surface; the data points were obtained from geophysical logs used in cross sections and from logs collected at deep oil test and injection wells where the base was penetrated. In areas of sparse well control, the base was estimated below the exploration depth of some wells by considering the general dip of the basal units along cross-sectional lines.

In some parts of the Floridan aquifer system, its effective base may lie at a higher altitude than depicted by the base of aquifer system raster (table 5). In north-central, central, and southern Florida, a low-resistivity zone indicating low permeability, thus the potential effective base of the aquifer system, lies between the base of the OLDSPZ and the base of the aquifer system. O'Reilly and others (2002, p. 24) revised the base of the Floridan upward in Orange County, Florida, and surrounding areas so that the low-resistivity evaporitic interval is excluded from the aquifer system in that area. Thus, in this report, the equivalent surface representing the low-resistivity zone could be used as the effective base of the Floridan (table 5).

\section{Salinity Boundaries}

The interface between freshwater and saltwater was defined in this study by the $10,000-\mathrm{mg} / \mathrm{L}$ TDS boundary (table 6). This boundary usually represents a relatively thin transition from fresh to saline water. Reese $(1994,2000,2004)$ and Reese and Memberg (2000) showed that the salinity transition zone from $10,000 \mathrm{mg} / \mathrm{L}$ to greater than $35,000 \mathrm{mg} / \mathrm{L}$ usually spans a few tens of feet to several hundred feet.

The raster surface representing the altitude of the estimated 10,000-mg/L TDS boundary (table 6) was constructed using geophysical logs and water-sample data from 257 wells. In addition to these data points, an additional 309 wells were used to represent the base of the aquifer system in areas where the aquifer contains water having less than $10,000 \mathrm{mg} / \mathrm{L}$ TDS. The resulting interpolated raster surface represents the altitude of the 10,000-mg/L TDS boundary or the physical base of the system, depending the presence or absence of saline water in the lower part of the aquifer.

Several polygon features showing the approximate position of the freshwater-saltwater boundary in selected hydrogeologic units were developed by intersecting the $10,000-\mathrm{mg} / \mathrm{L}$ TDS surface with the hydrogeologic unit surface. From this, polygon extents were constructed that represent saline areas for selected hydrogeologic units (table 6).

Table 6. Structural and thickness rasters and features depicting salinity boundaries in the Floridan aquifer system.

[APPZ, Avon Park permeable zone; LF, Lower Floridan aquifer; LISAPCU, Lisbon-Avon Park composite unit; LAPPZ, lower Avon-Park permeable zone; OLDSPZ, Oldsmar permeable zone; TDS, total dissolved solids; mg/L, milligrams per liter; >, greater than]

\begin{tabular}{|c|c|c|}
\hline Feature class $^{1}$ & Type & Description \\
\hline $\begin{array}{l}\text { fig21_LowResZone_below_OLDSPZ_ } \\
\text { saline_areas }\end{array}$ & Extent polygon & Area where estimated TDS $>10,000 \mathrm{mg} / \mathrm{L}$ at base of OLDSPZ \\
\hline fig22_thickness_FAS_saline_areas & Thickness & $\begin{array}{l}\text { Area where estimated TDS }>10,000 \mathrm{mg} / \mathrm{L} \text { is present in the lower part } \\
\text { of the aquifer system }\end{array}$ \\
\hline fig30_top_APPZ_saline_areas ${ }^{2}$ & Extent polygon & Area where estimated TDS $>10,000 \mathrm{mg} / \mathrm{L}$ at top of APPZ \\
\hline fig45_top_LF_below_LISAPCU_saline_areas ${ }^{3}$ & Extent polygon & Area where estimated TDS $>10,000 \mathrm{mg} / \mathrm{L}$ at top of LF below LISAPCU \\
\hline fig46_top_LAPPZ_saline_areas ${ }^{4}$ & Extent polygon & Area where estimated TDS $>10,000 \mathrm{mg} / \mathrm{L}$ at top of LAPPZ \\
\hline fig49_top_OLDSPZ_saline_areas & Extent polygon & Area where estimated TDS $>10,000 \mathrm{mg} / \mathrm{L}$ at top of OLDSPZ \\
\hline fig50_thickness_LF_saline_areas & Extent polygon & Area where estimated TDS $>10,000 \mathrm{mg} / \mathrm{L}$ at top of LF \\
\hline fig55_top_est_10000_TDS_boundary_raster & Structural & Altitude of the estimated $10,000-\mathrm{mg} / \mathrm{L}$ boundary \\
\hline fig55_top_est_10000_TDS_areas & Extent polygon & Areas depicting regions of the $10,000-\mathrm{mg} / \mathrm{L}$ map \\
\hline fig56_Thickness_FWZ_FAS_raster & Thickness & Thickness of the "freshwater" part of the Floridan aquifer system \\
\hline
\end{tabular}

${ }^{1}$ Feature class name is that listed for geodatabase. Point and contour features not listed.

${ }^{2}$ Derived by intersecting the estimated $10,000-\mathrm{mg} / \mathrm{L}$ surface with the top of the APPZ.

${ }^{3}$ Derived by intersecting the estimated $10,000-\mathrm{mg} / \mathrm{L}$ surface with the top of the LF below LISAPCU.

${ }^{4}$ Derived by intersecting the estimated $10,000-\mathrm{mg} / \mathrm{L}$ surface with the top of the LAPPZ. 


\section{Other Features}

Several additional feature classes in the dataset not described earlier include raster surfaces for geophysical marker horizons, an interpolated raster of regional transmissivity for the Upper Floridan aquifer (Kuniansky and others, 2012), an aquifer-wide potentiometric map for May 2010 (Kinnaman and Dixon, 2011), cross-section lines, key well location points used for the framework development, and feature classes representing the major structural features in the study area. County and State boundaries and feature classes representing the major streams are included as base-map features.

\section{References Cited}

Arthur, J.D., Fischler, C., Kromhout, C., Clayton, J.M., Kelley, G.M., Lee, R.A., Li, L., O'Sullivan, M., Green, R.C., and Werner, C.L., 2008, Hydrogeologic framework of the Southwest Florida Water Management District: Florida Geological Survey Bulletin 68, 102 p., accessed November 2, 2011, at http://ufdc.ufl.edu/ UF00087428/00002.

Arthur, J.D., Wood, H.A.R., Baker, A.E., Cichon, J.R., and Raines, G.L., 2007, Development and implementation of a Bayesian-based aquifer vulnerability assessment in Florida: Natural Resources Research, v. 16, no. 2, p. 93-107.

Barker, R.A. and Pernik, M., 1994, Regional hydrogeology and simulation of deep ground-water flow in the Southeastern Coastal Plain aquifer system in parts of Mississippi, Alabama, Georgia, and South Carolina: U.S. Geological Survey Professional Paper 1410-C, $87 \mathrm{p}$.

Brooks, R., Clarke, J.S., and Faye, R.E., 1985, Hydrogeology of the Gordon aquifer system of east-central Georgia: Georgia Geologic Survey Information Circular 75, 41 p.

Bush, P.W., and Johnston, R.H., 1988, Ground-water hydraulics, regional flow, and ground-water development of the Floridan aquifer system in Florida and in parts of Georgia, South Carolina, and Alabama: U.S. Geological Survey Professional Paper 1403-C, p. 80.

Campbell, B.G., and Coes, A.L., 2010, Groundwater availability in the Atlantic Coastal Plain of North and South Carolina: U.S. Geological Survey Professional Paper 1773, 241 p., 7 pls. (Also available at http://pubs.usgs.gov/ $\mathrm{pp} / 1773 /$.

Clarke, J.S., Hacke, C.M., and Peck, M.F., 1990, Geology and ground-water resources of the coastal area of Georgia: Georgia Geologic Survey Bulletin 113, 106 p.
Clayton, J.M., and McQuown, S.G., 1994, Final report of drilling and testing activities ROMP 39 (Oak Knoll) water resource assessment project-Manatee County, Florida: Manatee County, Southwest Florida Water Management District Report, December 1994, 460 p.

Fish, J.E., and Stewart, Mark, 1991, Hydrogeology of the surficial aquifer system Dade County, Florida: U.S. Geological Survey Water-Resources Investigations Report 90-4108, $50 \mathrm{p}$. (Also available at http://sofia.usgs.gov/publications/ wri/90-4108/.)

Gillett, B., Raymond, D.E., and Moore, J.D., 2004, Hydrogeology and vulnerability to contamination of major aquifers in Alabama-Area 11: Geologic Survey of Alabama Circular 199E, $97 \mathrm{p}$.

Hayes, L.R., and Barr, D.E., 1983, Hydrology of the sand-andgravel aquifer, southern Okaloosa and Walton Counties, northwest Florida: U.S. Geological Survey Water-Resources Investigations Report 82-4110, $43 \mathrm{p}$.

Hutchinson, C.B., 1992, Assessment of hydrogeologic conditions with emphasis on water quality and wastewater injection, southwest Sarasota and west Charlotte Counties, Florida: U.S. Geological Survey Water-Supply Paper 2371, 74 p.

Hutchinson, M.F., 1988, Calculation of hydrologically sound digital elevation models: Third International Symposium on Spatial Data Handling at Sydney, Australia.

Hutchinson, M.F., 1989, A new procedure for gridding elevation and stream line data with automatic removal of spurious pits: Journal of Hydrology, v. 106, p. 211-232.

Kinnaman, S.L., and Dixon, J.F., 2011, Potentiometric surface of the Upper Floridan aquifer in Florida and parts of Georgia, South Carolina, and Alabama, May-June 2010: U.S. Geological Survey Scientific Investigations Map 3182, 1 sheet. (Also available at http://pubs.usgs.gov/sim/3182/.)

Knochenmus, L.A., 2006, Regional evaluation of the hydrogeologic framework, hydraulic properties, and chemical characteristics of the intermediate aquifer system underlying southern west-central Florida: U.S. Geological Survey Scientific Investigations Report 2006-5013, 53 p.

Krause, R.E., and Randolph, R.B., 1989, Hydrology of the Floridan aquifer system in southeast Georgia and adjacent parts of Florida and South Carolina: U.S. Geological Survey Professional Paper 1403-D, 65 p.

Kuniansky, E.L., Bellino, J.C., and Dixon, J.F., 2012, Transmissivity of the Upper Floridan aquifer in Florida and parts of Georgia, South Carolina, and Alabama: U.S. Geological Survey Scientific Investigations Map 3204, 1 sheet, scale 1:100,000. (Also available at http://pubs.usgs.gov/sim/3204/.) 
LaRoche, J.L., 2007, The geology, hydrology, and water quality of the ROMP 43-Bee Branch monitor well site, Hardee County, Florida: Hardee County, Southwest Florida Water Management District, 257 p.

Lukasiewicz, J., 1992, A three-dimensional finite difference ground-water flow model of the Florida aquifer system in Martin, St. Lucie and eastern Okeechobee Counties, Florida: West Palm Beach: South Florida Water Management District Technical Publication 92-03, 292 p.

Maslia, M.L., and Hayes, L.R., 1988, Hydrogeology and simulated effects of ground-water development of the Floridan aquifer system, southwest Georgia, northwest Florida, and southernmost Alabama: U.S. Geological Survey Professional Paper 1403-H, 71 p.

McFadden, S.S., and Perriello, P.D., 1983, Hydrogeology of the Clayton and Claiborne aquifers in southwestern Georgia: Georgia Geologic Survey Information Circular IC-55, 59 p.

Miller, J.A., 1986, Hydrogeologic framework of the Floridan aquifer system in Florida and in parts of Georgia, Alabama, and South Carolina: U.S. Geological Survey Professional Paper 1403-B, 91 p.

Miller, J.A., 1990, Ground water atlas of the United States, Segment 6-Alabama, Florida, Georgia, and South Carolina: U.S. Geological Survey Hydrologic Investigations Atlas 730-G, 28 p. (Also available at http://pubs.usgs.gov/ ha/ha730/ch_g/index.html.)

Payne, D.F., Abu Rumman, M., and Clarke, J.S., 2005, Simulation of ground-water flow in coastal Georgia and adjacent parts of South Carolina and Florida-Predevelopment 1980 and 2000: U.S. Geological Survey Scientific Investigations Report 2005-5089, 91 p. (Also available at http://pubs.usgs.gov/sir/2005/5089/.)

Reese, R.S., 1994, Hydrogeology and the distribution and origin of salinity in the Floridan aquifer system, southeastern Florida: U.S. Geological Survey Water-Resources Investigations Report 94-4010, 56 p.

Reese, R.S., 2000, Hydrogeology and the distribution of salinity in the Floridan aquifer system, Southwestern Florida: U.S. Geological Survey Water-Resources Investigations Report 98-4253, 86 p.

Reese, R.S., 2004, Hydrogeology, water quality, and distribution and sources of salinity in the Floridan aquifer system, Martin and St. Lucie Counties, Florida: U.S. Geological Survey Water-Resources Investigations Report 03-4242, 96 p. (Also available at http://pubs.usgs.gov/wri/wri034242/.)
Reese, R.S., and Cunningham, K.J., 2000, Hydrogeology of the gray limestone aquifer in southern Florida: U.S. Geological Survey Water-Resources Investigations Report 99-4213, 244 p.

Reese, R.S., and Memberg, S.J., 2000, Hydrogeology and the distribution of salinity in the Floridan aquifer system, Palm Beach County, Florida: U.S. Geological Survey WaterResources Investigations Report 99-4061, 52 p.

Reese, R.S. and Richardson, E., 2008, Synthesis of the hydrogeologic framework of the Floridan aquifer system and delineation of a major Avon Park permeable zone in central and southern Florida: U.S. Geological Survey Scientific Investigations Report 2007-5207, 60 p., 64 pls., plus apps. (on CD).

Reilly, T.E., Dennehy, K.F., Alley, W.M., and Cunningham, W.L., 2008, Ground-water availability in the United States: U.S. Geological Survey Circular 1323, 70 p. (Also available at http://pubs.usgs.gov/circ/1323/.)

Renken, R.A., 1996, Hydrogeology of the Southeastern Coastal Plain aquifer system in Mississippi, Alabama, Georgia, and South Carolina: U.S. Geological Survey Professional Paper 1410-B, 101 p., 142 pls.

Scott, T.M., 1988, The lithostratigraphy of the Hawthorn Group (Miocene) of Florida: Florida Geological Survey Bulletin 59, 148 p.

Scott, T.M., 1990, The lithostratigraphy of the Hawthorn Group of peninsular Florida: Florida Geological Survey Open-File Report 36, 12 p.

Shoemaker, W.B., and Edwards, K.M., 2003, Potential for saltwater intrusion into the lower Tamiami aquifer near Bonita Springs, southwestern Florida: U.S. Geological Survey Water Resources Investigations Report 03-4262, 66 p. (Also available at http://fl.water.usgs.gov/Abstracts/ wri03_4262_shoemaker.html.)

Williams, L.J., and Kuniansky, E.L., 2015, Revised hydrogeologic framework of the Floridan aquifer system in Florida and parts of Georgia, Alabama, and South Carolina: U.S. Geological Survey Professional Paper 1807, 140 p., 140 p., 23 pls. (Also available at http://dx.doi.org/10.3133/ pp1807.)

Williams, L.J., Raines, J.E., and Lanning, A.E., 2013, Geophysical log database for the Floridan aquifer system and Southeastern Coastal Plain aquifer system in Florida and parts of Georgia, Alabama, and South Carolina: U.S. Geological Survey Data Series 760, 11 p. (Also available at http://pubs.usgs.gov/ds/760/.) 
Appendix 1 
Table 1-1. Content provided in the Floridan framework geodatabase.

[OCAPLPZ, Ocala-Avon Park low permeability zone; APPZ, Avon Park permeable zone; LISAPCU, Lisbon-Avon Park composite unit; MAPCU, middle Avon Park confining unit; LAPPZ, Lower Avon Park permeable zone; BZ, Boulder Zone; FPZ, Fernandina permeable zone; mg/L, milligrams per liter]

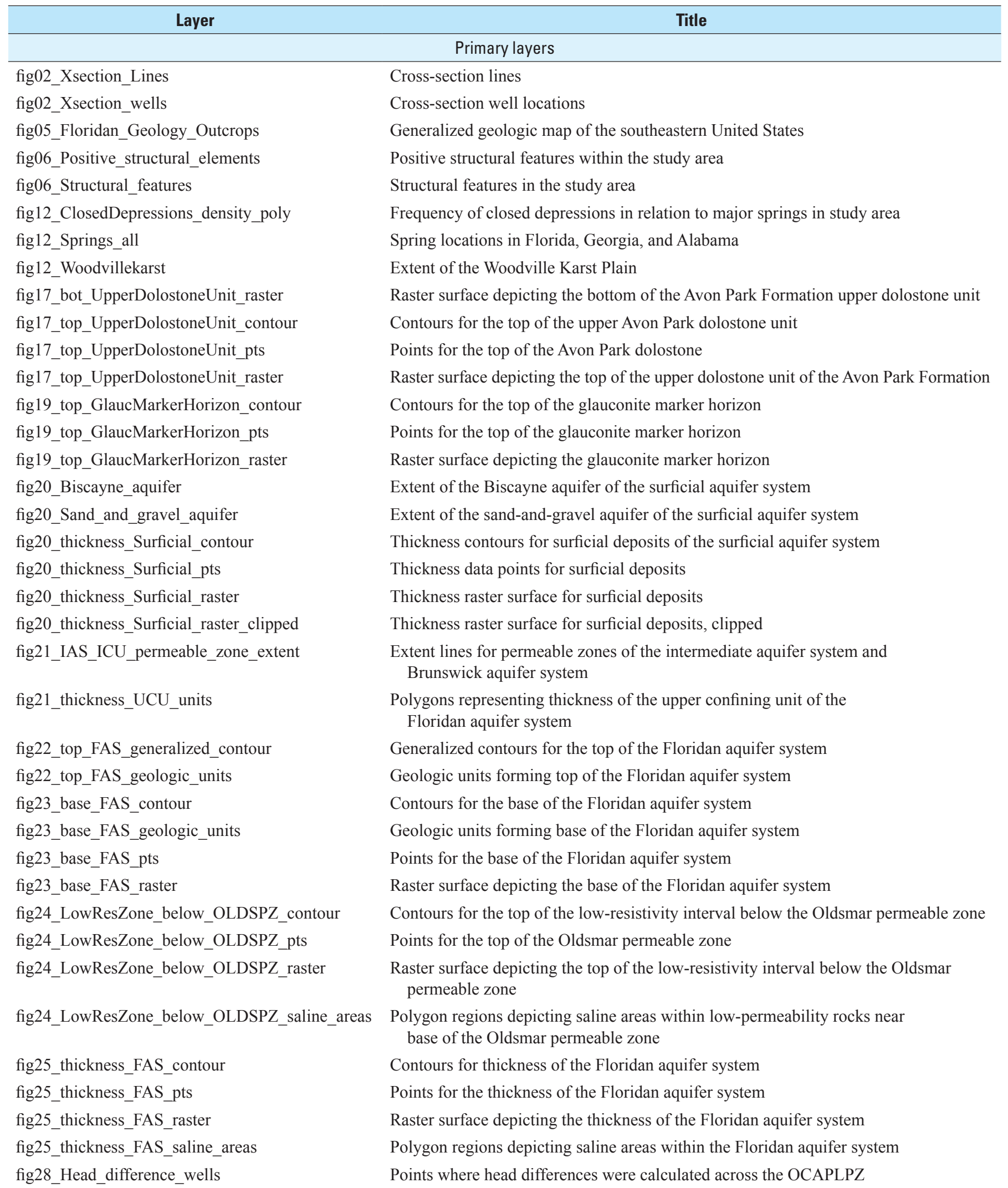


Table 1-1. Content provided in the Floridan framework geodatabase.-Continued

[OCAPLPZ, Ocala-Avon Park low permeability zone; APPZ, Avon Park permeable zone; LISAPCU, Lisbon-Avon Park composite unit; MAPCU, middle Avon Park confining unit; LAPPZ, Lower Avon Park permeable zone; BZ, Boulder Zone; FPZ, Fernandina permeable zone; mg/L, milligrams per liter]

\begin{tabular}{|c|c|}
\hline Layer & Title \\
\hline \multicolumn{2}{|r|}{ Primary layers-Continued } \\
\hline fig28_Head_gradient_areas & Head gradient regions (up or down) for the OCAPLPZ \\
\hline fig28_top_OCAPLPZ_extent & Clipping boundary extent for the OCAPLPZ \\
\hline fig28_top_OCAPLPZ_extent_line & Boundary line for the OCAPLPZ \\
\hline fig28_top_OCAPLPZ_raster & Raster surface depicting the altitude of the top of the OCAPLPZ \\
\hline fig30_Limestone_line & Limestone boundary for the APPZ (Reese and Richardson, 2008) \\
\hline fig30_top_aggregated_APPZ_contour & Contours for the top of the APPZ \\
\hline fig30_top_aggregated_APPZ_extent & Clipping boundary extent of the APPZ \\
\hline fig30_top_aggregated_APPZ_pts & Points for the top of the APPZ \\
\hline fig32_thickness_UF_contour & Contours for the thickness of the Upper Floridan aquifer \\
\hline fig32_thickness_UF_lowPerm_units & $\begin{array}{l}\text { Polygon regions of low permeability units forming the base of the } \\
\text { Upper Floridan aquifer }\end{array}$ \\
\hline fig32_thickness_UF_pts & Points for the thickness of the Upper Floridan aquifer \\
\hline fig32_thickness_UF_raster & Raster surface depicting the thickness of the Upper Floridan aquifer \\
\hline fig33_top_LISAPCU_contour & Contours for the top of the LISAPCU \\
\hline fig33_top_LISAPCU_extent & Clipping boundary extent for the LISAPCU \\
\hline fig33_top_LISAPCU_MCUI_dolostone & Polygon regions of low-permeability units forming the LISAPCU \\
\hline fig33_top_LISAPCU_pts & Points for top of the LISAPCU \\
\hline fig38_top_MAPCU_MCUII_IB_III_pts & Points for the top of the MAPCU \\
\hline fig38_top_MAPCU_raster & Raster surface depicting the top of the MAPCU \\
\hline fig38_top_MAPCU_regions & Polygon regions of low-permeability units forming the MAPCU \\
\hline fig43_bot_Bucatunna_raster & Raster surface depicting the bottom of the Bucatunna clay confining unit \\
\hline fig43_top_Bucatunna_contour & Contours for the top of the Bucatunna clay confining unit \\
\hline fig43_top_Bucatunna_extent & Clipping boundary extent for the Bucatunna clay confining unit \\
\hline fig43_top_Bucatunna_pts & Points for the top of the Bucatunna clay confining unit \\
\hline fig43_top_Bucatunna_raster & Raster surface depicting the top of the Bucatunna clay confining unit \\
\hline fig43_top_Bucatunna_regions & Clipping boundary extent for the Bucatunna clay confining unit \\
\hline fig44_top_LF_contour & Contours for the top of the Lower Floridan aquifer \\
\hline fig44_top_LF_MCU_regions & $\begin{array}{l}\text { Polygon regions depicting the low-permeability units that overlie the } \\
\text { Lower Floridan aquifer }\end{array}$ \\
\hline fig44_top_LF_pts & Points for the top of the Lower Floridan aquifer \\
\hline fig44_top_LF_raster & Raster surface depicting top of the Lower Floridan aquifer \\
\hline
\end{tabular}


Table 1-1. Content provided in the Floridan framework geodatabase.-Continued

[OCAPLPZ, Ocala-Avon Park low permeability zone; APPZ, Avon Park permeable zone; LISAPCU, Lisbon-Avon Park composite unit; MAPCU, middle Avon Park confining unit; LAPPZ, Lower Avon Park permeable zone; BZ, Boulder Zone; FPZ, Fernandina permeable zone; mg/L, milligrams per liter]

\begin{tabular}{|c|c|}
\hline Layer & Title \\
\hline \multicolumn{2}{|r|}{ Primary layers-Continued } \\
\hline fig45_top_LF_below_LISAPCU_contour & Contours for the top of the first permeable zone below the LISAPCU \\
\hline fig45_top_LF_below_LISAPCU_pts & Points for the top of the Lower Floridan aquifer below the LISAPCU \\
\hline fig45_top_LF_below_LISAPCU_pts_constrained & Points for the top of the Lower Floridan aquifer below the LISAPCU, constrained \\
\hline fig45_top_LF_below_LISAPCU_saline_areas & $\begin{array}{l}\text { Polygon regions depicting saline areas within the first permeable zone below } \\
\text { the LISAPCU }\end{array}$ \\
\hline fig46_top_LAPPZ_contour & Contours for the top of the LAPPZ \\
\hline fig46_top_LAPPZ_extent & Clipping boundary extent for the LAPPZ \\
\hline fig46_top_LAPPZ_pts & Points for the top of the LAPPZ \\
\hline fig48_top_GlaucUnit_extent & Clipping boundary extent for the glauconite marker unit \\
\hline fig48_top_GlaucUnit_pts & Points for the top of the glauconite marker unit \\
\hline fig48_top_GlaucUnit_raster & Raster surface depicting top of the glauconite marker unit \\
\hline fig48_top_GlaucUnit_regions & Polygon regions of the glauconite marker unit \\
\hline fig49_top_OLDSPZ_BZ_area_Miller & Polygon extent of the BZ region of the Oldsmar permeable zone \\
\hline fig49_top_OLDSPZ_contour & Contours for the top of the Oldsmar permeable zone \\
\hline fig49_top_OLDSPZ_extent & Clipping boundary extent for the Oldsmar permeable zone \\
\hline fig49_top_OLDSPZ_FPZ_area_Miller & Extent of the FPZ region of the Oldsmar permeable zone \\
\hline fig49_top_OLDSPZ_pts & Points for the top of the Oldsmar permeable zone \\
\hline fig50_thickness_LF_saline_areas & Polygon regions depicting saline areas of the Lower Floridan aquifer \\
\hline fig51_Springs & Spring locations used in the transmissivity map \\
\hline fig51_Transmissivity & Raster surface for transmissivity of the Upper Floridan aquifer \\
\hline fig51_Transmissivity_wells & Estimated transmissivity of the Upper Floridan aquifer \\
\hline fig53_Major_GW_divides & Major groundwater divides of the Floridan aquifer system \\
\hline fig53_May2010_Potentiometric_contour & Potentiometric surface contours of the Upper Floridan aquifer in May 2010 \\
\hline fig53_May2010_Potentiometric_wells & $\begin{array}{l}\text { Well locations used in the development of the potentiometric surface map for } \\
\text { the Upper Floridan aquifer in May } 2010\end{array}$ \\
\hline fig54_Apalachicola_salinity_feature & Extent of the Apalachicola salinity feature \\
\hline fig54_top_est_10000_TDS_areas & Polygon regions for the $10,000 \mathrm{mg} / \mathrm{L}$ total dissolved solids boundary feature \\
\hline fig54_top_est_10000_TDS_boundary_contour & Estimated altitude of the $10,000 \mathrm{mg} / \mathrm{L}$ total dissolved solids boundary \\
\hline fig54_top_est_10000_TDS_boundary_pts & Points for the top of the $10,000 \mathrm{mg} / \mathrm{L}$ total dissolved solids boundary \\
\hline fig54_top_est_10000_TDS_boundary_pts_Control & Points and control points for the top of the $10,000 \mathrm{mg} / \mathrm{L}$ total dissolved solids boundary \\
\hline fig54_top_est_10000_TDS_boundary_raster & $\begin{array}{l}\text { Raster surface generated for the } 10,000 \mathrm{mg} / \mathrm{L} \text { total dissolved solids boundary across } \\
\text { the study area }\end{array}$ \\
\hline
\end{tabular}


Table 1-1. Content provided in the Floridan framework geodatabase.—Continued

[OCAPLPZ, Ocala-Avon Park low permeability zone; APPZ, Avon Park permeable zone; LISAPCU, Lisbon-Avon Park composite unit; MAPCU, middle Avon Park confining unit; LAPPZ, Lower Avon Park permeable zone; BZ, Boulder Zone; FPZ, Fernandina permeable zone; mg/L, milligrams per liter]

\begin{tabular}{|c|c|}
\hline Layer & Title \\
\hline \multicolumn{2}{|r|}{ Primary layers - Continued } \\
\hline fig55_thickness_FWZ_FAS_contours & Contours for the freshwater thickness of the Floridan aquifer system \\
\hline fig55_thickness_FWZ_FAS_raster & Raster surface generated for the freshwater thickness of the Floridan aquifer system \\
\hline mcu_regional_contour & Contours for top of the middle confining unit of the Floridan aquifer system \\
\hline mcu_regional_pts_constrained & $\begin{array}{l}\text { Point features used for the top of the regional middle confining unit (base of } \\
\text { Upper Floridan aquifer), constrained }\end{array}$ \\
\hline mcu_regional_raster & $\begin{array}{l}\text { Raster surface depicting the top of the regional middle confining unit (base of } \\
\text { Upper Floridan aquifer) }\end{array}$ \\
\hline plate1_key_wells & Key well sites \\
\hline plate1_xsection_wells & Wells used in cross-sections \\
\hline plate3_hawthorn_absent & Area where upper confining unit is thin or absent beneath the surficial aquifer \\
\hline plate3_thickness_UCU_contours & Contours for thickness of the upper confining unit of the Floridan aquifer system \\
\hline plate3_thickness_UCU_pts & Point features for the thickness of the upper confining unit \\
\hline plate3_thickness_UCU_raster & Raster surface depicting the thickness of the upper confining unit \\
\hline plate3_thickness_UCU_regions & Thickness regions of the upper confining unit \\
\hline plate3_Updip_limit_confining_unit & $\begin{array}{l}\text { Line showing approximate updip limit of the upper confining unit of the } \\
\text { Floridan aquifer system }\end{array}$ \\
\hline plate3_Updip_limit_upper_Floridan & $\begin{array}{l}\text { Line showing the updip limit of the permeable upper Floridan aquifer system } \\
\text { in a local area }\end{array}$ \\
\hline plate4_Top_FAS_pts_constrained & Points for the top the Floridan aquifer system, constrained \\
\hline plate4_Top_FAS_raster & Raster surface depicting the top of the Floridan aquifer system \\
\hline plate5_base_FAS_contours & Contours for the base of the Floridan aquifer system \\
\hline plate5_base_FAS_geo_units & Geologic units forming the base of the Floridan aquifer system \\
\hline plate5_base_FAS_pts & Point features used for the base of the Floridan aquifer system \\
\hline plate5_base_FAS_raster & Raster surface depicting the base of the Floridan aquifer system \\
\hline plate6_thickness_FAS_contours & Contours for thickness of the Floridan aquifer system aquifer \\
\hline plate6_thickness_FAS_pts & Point features for the thickness of the Floridan aquifer system \\
\hline plate6_thickness_FAS_raster & Raster surface depicting the thickness of the Floridan aquifer system \\
\hline plate6_thickness_FAS_saline_areas & Polygon regions depicting saline areas within the Floridan aquifer system \\
\hline thickness_aggregated_APPZ_pts & Points for the thickness of the APPZ \\
\hline thickness_aggregated_APPZ_raster_ss & Raster surface depicting the thickness of the aggregated APPZ \\
\hline thickness_Bucatunna_pts & Points for the thickness of the Bucatunna clay confining unit \\
\hline thickness_Bucatunna_raster_ss & Raster surface depicting the thickness of the Bucatunna clay confining unit \\
\hline
\end{tabular}


Table 1-1. Content provided in the Floridan framework geodatabase.-Continued

[OCAPLPZ, Ocala-Avon Park low permeability zone; APPZ, Avon Park permeable zone; LISAPCU, Lisbon-Avon Park composite unit; MAPCU, middle Avon Park confining unit; LAPPZ, Lower Avon Park permeable zone; BZ, Boulder Zone; FPZ, Fernandina permeable zone; mg/L, milligrams per liter]

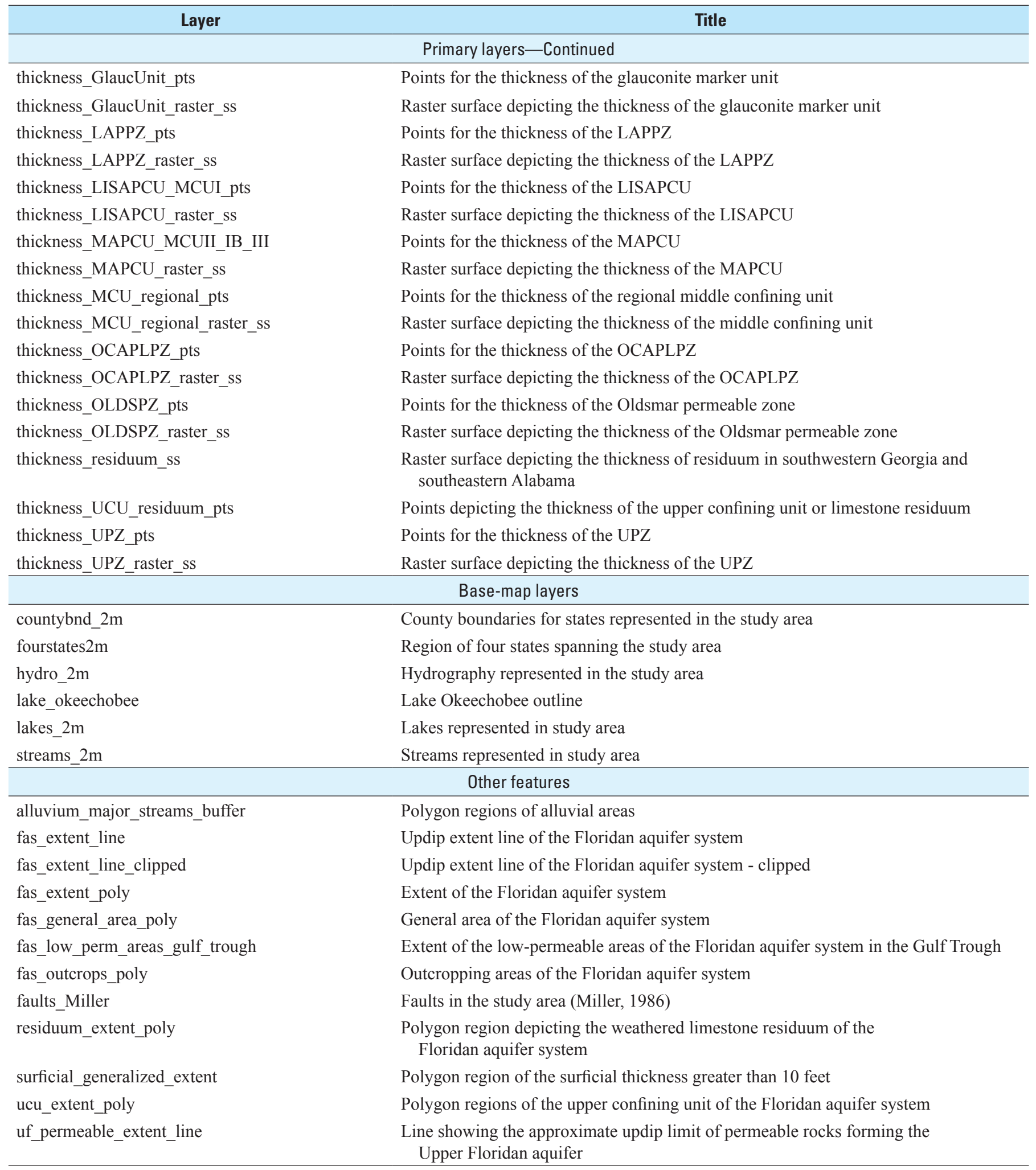


Manuscript approved March 4, 2015

Prepared by the USGS Science Publishing Network Raleigh Publishing Service Center Edited by Michael Deacon

Illustrations and layout by Caryl J. Wipperfurth

For more information concerning this report, contact: Director

U.S. Geological Survey

Caribbean-Florida Water Science Center 4446 Pet Lane, Suite 108

Lutz, FL 33559

(813) 498-5000

or visit our Web site at: http://fl.water.usgs.gov 


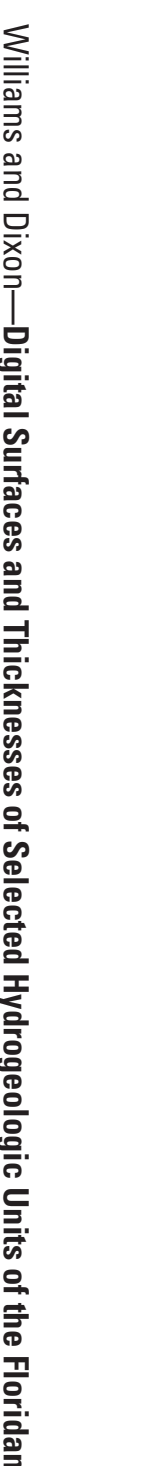

总 